\title{
Выпускники Императорской академии художеств и Петербургского института гражданских инженеров - авторы харьковских зданий
}

\author{
Т.Ф.Давидич, ХНУСА, Харьков, Украина
}

В статье рассматриваются творческие биографии и основные постройки иногородних авторов харьковских зданий - выпускников Императорской академии художеств и Петербургского института гражданских инженеров (конец XIX века - 1930-е годы XX века).

Graduates of the Imperial Academy of Arts and the Petersburg Institute Of Civil Engineers - Authors of the Kharkov Buildings

T.F.Davidich, KNUCEA, Kharkov, Ukraine

The article discusses creative biographies and the main buildings of non-resident authors of Kharkov buildings graduates of the Imperial Academy of Arts and the St. Petersburg Institute of Civil Engineers (end of the 19th century - the 1930s of the 20th century).

До установления советской власти в 1917 году Харьков был крупным губернским центром Российской империи, поэтому архитектурные процессы здесь происходили в русле общих для всей империи тенденций. В период 1765 - 1780 годов, когда Харьков был центром СлободскоУкраинской губернии и главным городом Харьковского наместничества (этот период был связан с началом правления царицы Екатерины II), началась реконструкция центра города, которая предусматривала создание единого классицистического ансамбля (как было принято в то время). Период правления Николая I уже значительно отличался от предыдущих в связи с резким изменением социальноэкономической и культурной ситуации в стране. Первые попытки отступлений от классицистических архитектурных традиций в сторону эклектики стали проявляться в Харькове с 1840-х годов, когда заказчики получили бо́льшую свободу в выборе архитектурных решений и отпала необходимость согласовывать проекты с Петербургом - они стали утверждаться местными городскими инстанциями. С 1858 года в Российской империи было отменено обязательное применение «образцовых проектов», и появилась возможность свободного выбора стиля как частных, так и общественных зданий.

В 1869 году в Харкове появилась железная дорога, которая удобно связала его с Москвой, Санкт-Петербургом и Крымом. Это способствовало превращению Харькова в один из крупнейших важных транспортных узлов Российской империи. Успехи экономического развития обусловили активный рост населения города, расширение его территории, ускорение темпов застройки, рост этажности домов. Стали формироваться новые улицы в центральной части города - Сумская, Немецкая, Екатеринославская, между которыми сложилась целая сеть новых улиц. Ведущие архитекторы Харкова того времени были, в основном, выпускниками Императорской академии художеств и Петербургского института гражданских инженеров. В 1885 году был открыт Харьковский технологический институт, в котором началась подготовка гражданских инженеров. Многие из них впоследствии работали практикующими архитекторами в Харькове. С 1893 года в городе начали появляться частные архитектурно-строительные конторы и бюро. Бурное развитие капитализма способствовало строительству промышленных предприятий и вместе с этим - быстрому увеличению населения города.

Начало XX века было связано с эпохой модерна. Так же, как и во всех крупных городах Российской империи, в Харькове она обозначилась расцветом культурной жизни. В архитектуре появилось очень много идей и направлений, начался настоящий строительный бум. С 1910 года появилась городская канализация, что способствовало появлению многоэтажных жилых домов на центральных улицах города. Благодаря развитию системы банков и страховых компаний началось строительство многоэтажных доходных жилых домов (до семи этажей), оборудованных лифтами, мусоропроводами и внутренними ливнестоками, гостиниц, банковских зданий, заводских цехов, железнодорожных депо и мастерских, электростанций, промышленных мельниц, мануфактур, торговых зданий, пассажей, складов, вокзалов, театров, цирков, первых кинотеатров. В город регулярно поступали архитектурно-художественные периодические издания. Свободный доступ к профессиональной периодической печати, проведение архитектурных конкурсов, создание архитектурных обществ, общественные обсуждения архитектурных проектов способствовали установлению тесных рабочих контактов со столичными архитекторами и обмену опытом творчески активных зодчих в пределах всей империи. Многие здания в Харькове строились по проектам (в том числе конкурсным) санкт-петербургских и московских авторов.

В данной статье автор хочет показать наиболее значительные реализованные в Харькове постройки архитекторов-нехарьковчан - выпускников императорской Академии художеств и Петербургского института гражданских инженеров. 
Алёшин Павел Федотович (Киев, 1881-1961)
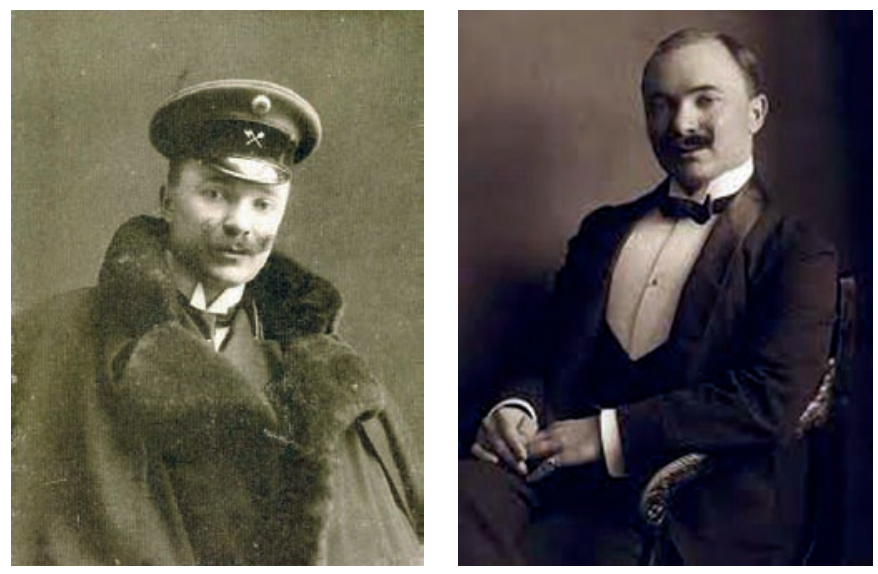

Родился в Киеве, в семье выходца из крепостных крестьян. Обучался в рисовальной школе художника-педагога Николая Мурашко. Окончил ИГИ в 1904 году, ИАХ в 1917-ом со званием художника-архитектора. В 1900-м и 1902 годах за отличную учёбу был премирован ознакомительными заграничными поездками в Грецию и ведущие европейские страны.

В 1907-1909 годы в Санкт-Петербурге по его проекту был построен дом Торгово-промышленного товарищества Бажанова и Чувалдиной (интерьеры выполнены при участии художников Н. Рериха и М. Врубеля). П.Ф. Алёшин был также автором нескольких конкурсных проектов учебных заведений для Киева, Вятки, Казани. Также по его проекту в 1912 году в стиле неоклассицизма был построен в Киеве педагогический музей им. Цесаревича Алексея. В 1917 году он выполнил конкурсный проект планировки города-сада «Зелёный Петроград» (3-я премия) [1-3].

В 1918-1920 годы П. Ф. Алёшин был главным архитектором Киева, в 1922-1924 годы - киевским губернским архитектором. В 1921-ом он стал профессором архитектуры в Киевском политехническом институте и профессором Киевского архитектурного института, в 1923-ем - профессором Киевского художественного института. В 1945 году - выбран действительным членом Академии архитектуры уССР, членом президиума и вице-президентом Академии архитектуры УССР. В 1945-ом - исполняющий обязанности директора Института восстановления городов и сёл Украины. В том же году ему была присуждена II-я премия за конкурсный проект восстановления Крещатика (с участием арх. А.О. Колесниченко). С 1946 года - доктор архитектуры.

В 1930-1931 годах П.Ф. Алёшин был руководителем коллектива по составлению проекта соцгорода «Новый Харьков» на 113 тысяч жителей для Харьковского тракторного завода [4]. Это был крупный жилой массив нового типа, в котором внедрялись популярные в среде конструк- тивистов идеи социального переустройства общества при помощи архитектуры. Он предназначался для работников ХТ3 и был компактно размещён в восточной части города (на продолжении линии Московского проспекта в пригородную зону). Предполагалось, что он будет включать в себя полную инфраструктуру, обеспечивающую быт и досуг жителей. В нём воплощалась идея «города будущего», где все функции - производственные, жилые и обслуживающие - должны были обеспечиваться централизованно и в наиболее удобных связях друг с другом. От заводской территории этот компактный жилой район отделялся широкой зелёной полосой (рис. 1).

Строительство соцгорода «Новый Харьков» осталось незавершённым, так как в 1933 году в архитектуре СССР был осуществлён резкий переход к «сталинскому» стилю, а идеи модернизма и конструктивизма стали подвергаться резкой критике.

П.Ф. Алёшин был также одним из авторов конкурсного проекта Дворца правительства для Харькова (1928, соавторы В.И. Заболотный, П.Г. Юрченко, 5-я премия). В 1944-1949 годах он руководил послевоенной реставрацией Киевского университета и Мариинского дворца [3].

В своей работе П.Ф. Алёшин применял стили неоклассицизм, модерн, конструктивизм, работал также в эклектике и «сталинском» стиле. Имел ряд публикаций по вопросам архитектурного проектирования и отделки фасадов различных типов зданий, по творческим биографиям архитекторов В.И. и А.В. Беретти. Среди его учеников были известные украинские архитекторы: П. Юрченко, В. Заболотный, П. Шпара, И. Каракис, Г. Волошинов, А. Колесниченко, Я. Штейнберг, С. Барзилович $[3 ; 5]$.

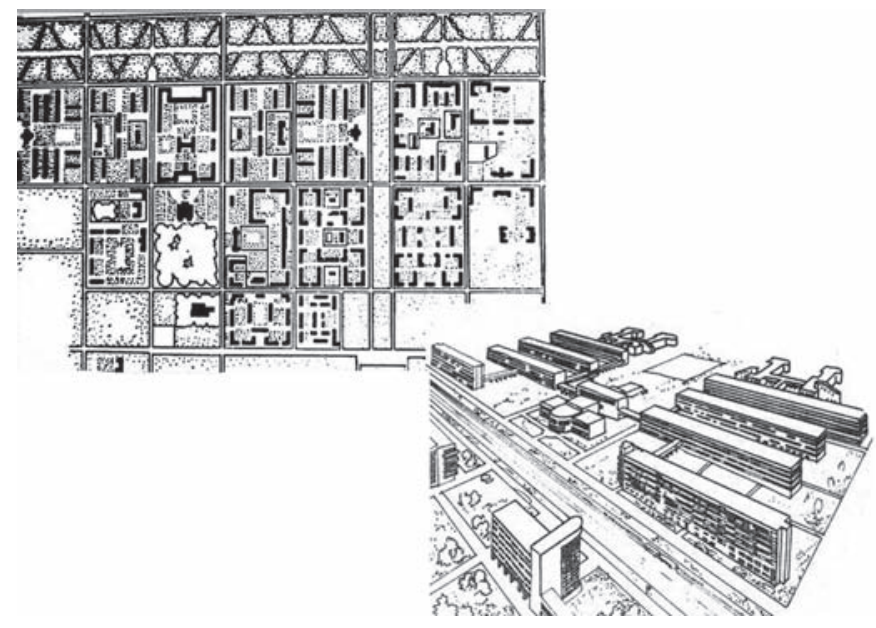

Pис. 1. Соцгород ХТЗ. Генеральный план, фрагмент общего вида застройки. Проект, выполненный проектно-консультационным бюро при НКВД УССР под руководством профессора П.Ф. Алешина. 1930-1931 годы (источник: https://ngeorgij. livejournal.com/7844.html) 
Васильев Николай Васильевич (Санкт-Петербург, 1875-1940-e)

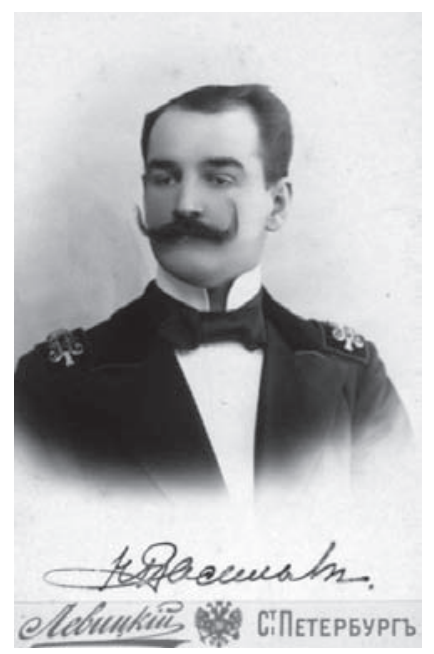

В 1896-1901 годах учился в ИГИ. Его соучениками были известные в будущем архитекторы П.Ф. Алёшин, В.В. Верёвкин, А.И. Дмитриев. В 1904 году окончил ИАХ по мастерской Л.Н. Бенуа, после чего служил в Строительной экспедиции «Канцелярии по учреждениям императрицы Марии», занимался ремонтом, реставрацией и реконструкцией сооружений в Санкт-Петербурге. Работал под руководством известных архитекторов. В 1900-е - 1910-е годы создал множество конкурсных проектов, отличавшихся большим разнообразием стилевых и композиционных решений. Считался лучшим в Санкт-Петербурге мастером Северного модерна [6]. Кроме чисто архитектурных решений разрабатывал системы пластических и декоративных элементов, в том числе - взятых из восточной архитектуры. Его архитектурные проекты отличались разнообразием, красотой планировочных решений, выразительностью и динамичностью объёмных форм,

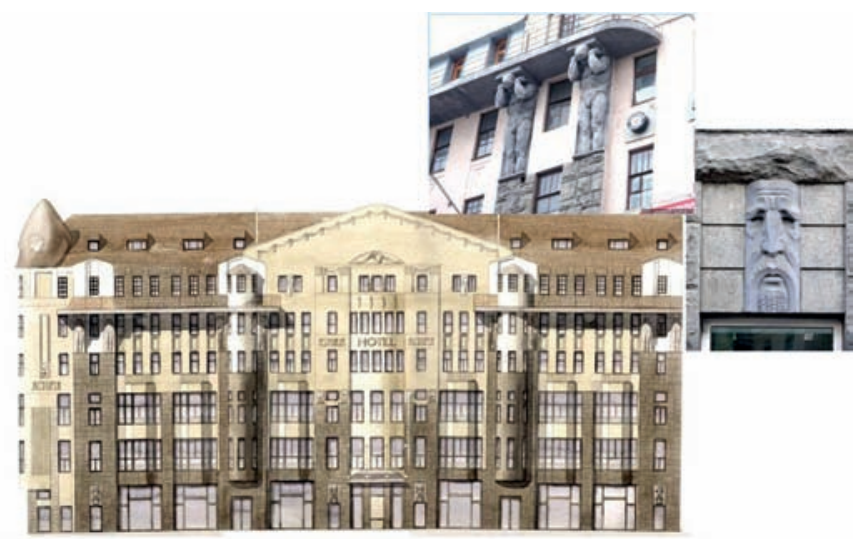

Pис. 2. Здание бывшего Купеческого банка и гостиницы «Астория». Архитекторы Н.В. Васильев и А.И. Ржепишевский. 1909-1913 годы (источники: https://www.sq.com.ua) rus/news/novosti/18.07.2017/fasady_rozenfelda/ u фomo T. Ф. Давидич) хорошими связями интерьеров с внешним пространством [6, с. 844]. Васильев не связывал себя жёсткими рамками стилевых течений и работал одновременно с применением многих стилевых форм, характерных для эпохи модерна [7-9]. Много времени архитектор уделял живописи, рисунку и плакатной графике, в которых проявил себя выдающимся мастером. Охватывал широкий типологический круг объектов - от особняков и доходных домов до крупных жилых комплексов, здравниц, храмовых сооружений, театральных, торговых, промышленных и банковских зданий. Среди реализаций его промышленных проектов есть такие, как здание промышленного корпуса Невской ниточной мануфактуры на Выборгской набережной, здание мебельной фабрики Лютера в Таллинне и там же - здание судостроительного завода «Руссо-Балт». В 1912 году выполнил конкурсный проект Художественной школы в Харькове.

Н.В. Васильев в своих проектах достаточно часто использовал железобетонный каркас, что позволяло применять на фасадах большие площади остекления, которые, как правило, сочетались с отделкой фасадов блоками «рваного» естественного камня. В 1908 году он принимал участие в первой в Российской империи строительной выставке на Каменном острове, к которой были привлечены участники из ведущих европейских стран. От этой выставки до настоящего времени сохранился навес из монолитного железобетона, установленный в Каменноостровском парке. Кроме архитектуры увлекался техникой и авиацией, был восприимчив к техническим новинкам. В модерне он ценил не столько внешнюю декоративность, сколько новизну конструктивных решений с применением металла, железобетона и крупноразмерного стекла и возможность создания пластичных и остро-характерных форм, которые можно было реализовать только с применением новейших конструкций. При этом выразительная пластика и монументальная мощь архитектурных форм в его постройках сочеталась с модернизованными романтическими фольклорными и античными образами скульптурной пластики. Многие годы работал в сотрудничестве с архитектором Алексеем Бубырём, который погиб в конце Гражданской войны [8]. С 1918 года работал в Турции, Сербии, США. Одно время был Главным архитектором Нью-Йорка [8].

В Харькове по конкурсному проекту, выполненному Н.В. Васильевым в соавторстве с А.И. Ржепишевским, скульпторами Н. Козловым, Л. Дитрихом, в 1909-1913 годах были построены здание гостиницы «Астория» и Купеческого банка на Павловской площади (ныне - площадь Соборной Украины) (рис. 2), а также - здание Торгового дома купца Бакакина на улице Рождественской, 19 (позже - Энгельса. 1914, соавтор А.И. Ржепишевский) (рис. 3). В 1920-е годы, живя в США, Н.В. Васильев работал в формах модернизма, в 1930-х - в формах ар-деко [8; 9]. Участвовал во множестве международных конкурсов, в том числе - на здание Госпрома в Харькове (1925) (рис. 4) и Дворца Советов в Москве (1932). 


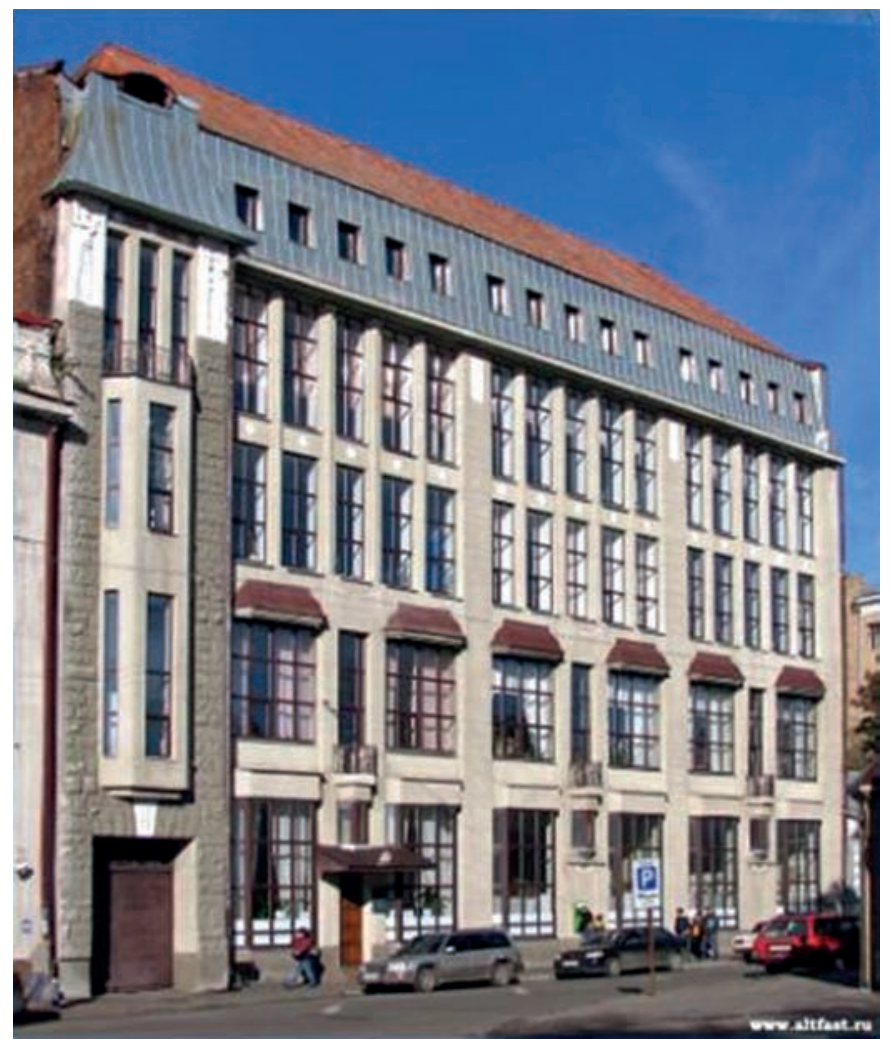

Pис. 3. Здание бывшего Торгового дома купца Бакакина на улице Рождественской, 19. Архитекторы Н.В. Васильев, А.И. Ржепишевский, 1910-е годы. Фото Т.Ф. Давидич

\section{Верёвкин Николай Николаевич (1877-1920)}

Окончил ПИГИ в 1901 году, с 1904 по 1906 гг. обучался в ИАХ. Получил звание художника-архитектора за проект: «Кафедральный собор для губернского города». Был членом Петербургского общества архитекторов. Работал в основном в стилевом течении неоклассицизма, характерном для архитектуры Санкт-Петербурга начала XX века. Проектировал многоэтажные доходные дома и дома-комплексы в основном для страхового общества «Саламандра», а также производственные и жилые здания для мёдопивоваренного завода «Бавария», частные особняки [10; 11]. В Харькове по его проекту был построен дом-комплекс страхового общества «Саламандра» на улице Сумской, 17 [12] (рис. 5). Этот проект представлял собой несколько переработанный вариант конкурсного проекта студентов Бердникова и Редькина, выигравших конкурс на данное здание. Также по проекту Н.Н. Верёвкина были построены доходные дома страхового общества «Саламандра» в Санкт-Петербурге и Омске, а также дом товарищества «Треугольник» в 0мске. Его проекты публиковались в Ежегоднике 0бщества архитекторов-художников.

«Шестиэтажное здание с подвалом, имеющее весьма сложную конфигурацию в плане, плотно вписано в участок и занимает около 70 процентов его площади. Шестьдесят четыре квартиры со всеми удобствами размещены в пяти секциях.

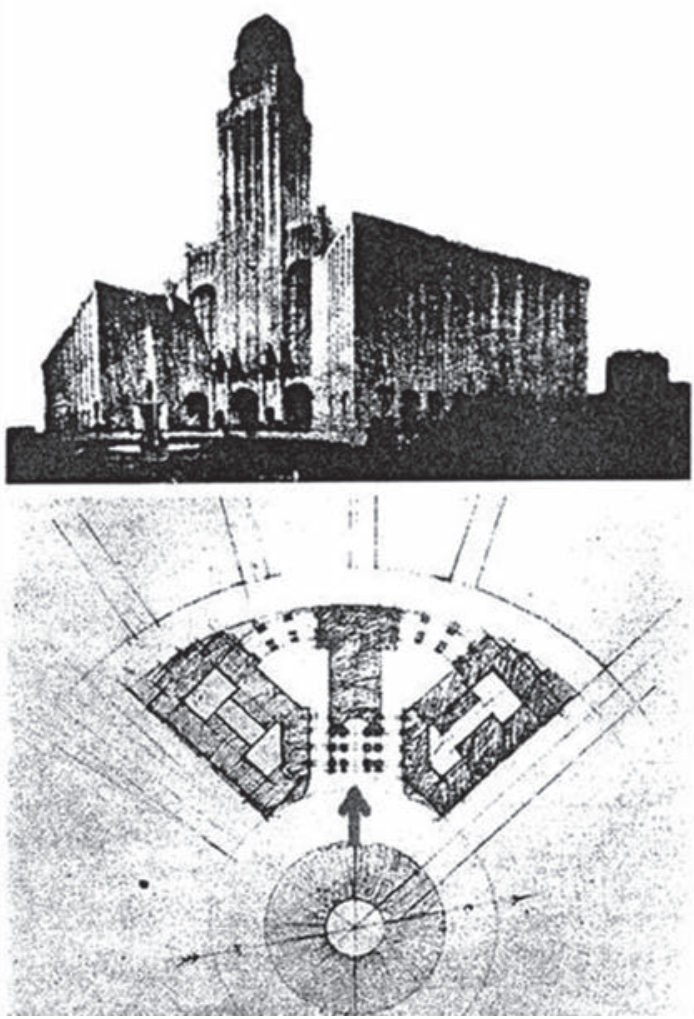

Рис. 4. Конкурсный проект на здание Госпрома в Харькове. Архитектор Н.В. Васильев. 1925 год (источник: http:// balakliets.kharkov.ua/arkhitekturnye-pamiatniki/gosprom)

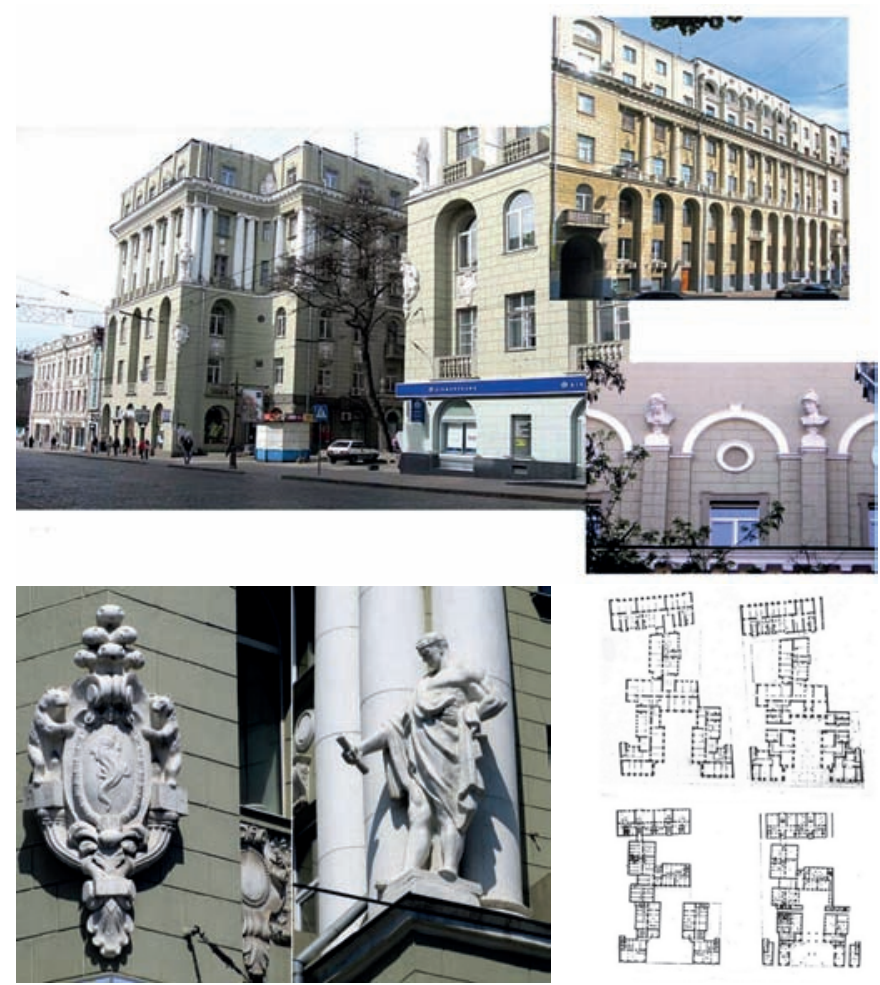

Рис. 5. Бывший доходный дом страхового общества «Саламандра» в Харькове на улище Сумской, 17. Архитектор Н.Н. Верёвкин. 1913-1916 годы (источники: http://the-past.inf. ua/list-2-3-5.html и фото Т.Ф. Давидич) 
Трёхмаршевые парадные лестницы и лифты, перед входом в которые со стороны улицы расположены небольшие вестибюли и обращённые во дворы «чёрные» лестницы, обслуживают каждую секцию. На первом этаже со стороны Сумской улицы обустроены магазины. Тесные дворы-колодцы связаны между собой узкими проездами. Фасад здания, решённый в стиле неоклассицизма, отличается совершенством пропорций и багатством пластики. Украшением дома служат выполненные в античном духе монументально-декоративные скульптуры (одно из требований заказчиака - «спокойные и солидные фасады, без модерна и декаданса» [13].

\section{Гевирц Яков (Моисей) Германович (1879-1942)}
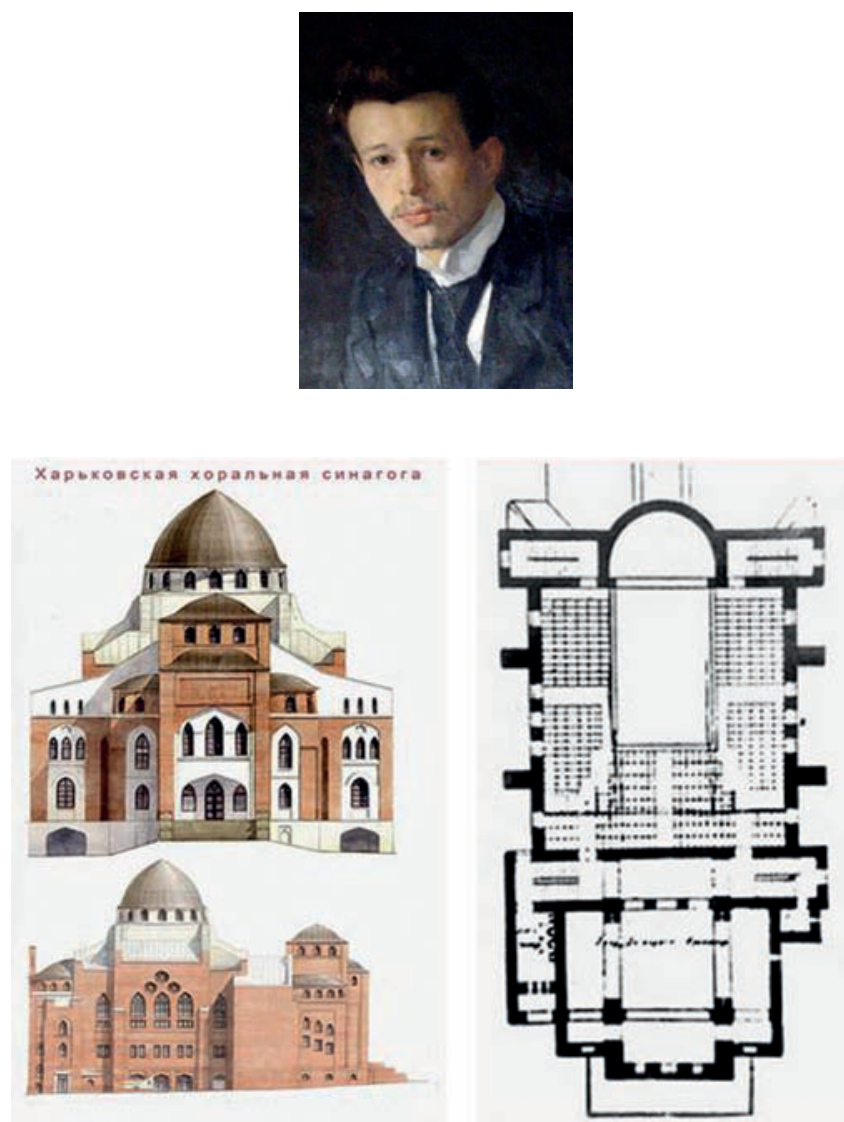

a)

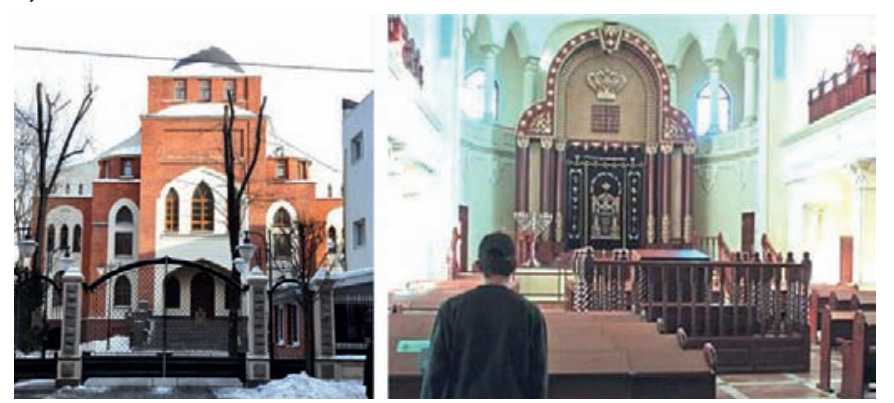

б)

Рис. 6. Харьковская хоральная синагога «Бейт Менахем». Архитекторы Я.Г. Гевири, В.А.Фельдман, М.Ф. Пискунов. 1910 1913 годы: а) фасад, план (источник: https://chrontime. com/object-harkovskaya-horalnaya-sinagoga); б) общий вид, интерьер зала. Фото Т.Ф. Давидич
Родился в Одессе. В 1899-1906 годах учился в Высшем художественном училище при Императорской академии художеств по мастерской Леонтия Николаевича Бенуа. Действительный член Археологического института, в 1910-е годы был секретарём Общества архитекторов-художников, в 1910-1917 годы - секретарь Императорского общества поощрения художеств, с 1915-го - член правления Еврейского общества поощрения художеств, с 1922-го - преподаватель Академии художеств, с 1925-го - профессор Академии художеств, с 1936-го - декан архитектурного факультета Академии художеств, автор трудов по истории и теории архитектуры, а также учебника «История античной архитектуры» [14].

Многие его реализованные проекты связаны с заказами еврейской общины. Это здания синагог. В числе его произведений здания синагоги на Преображенском еврейском кладбище и кинематографа «Колизей» на Кронверкском проспекте; особняк В.А. Тяничева на Кирилловской улице, доходный дом акционерного общества «Строитель» на проспекте Добролюбова, дома А.Ф. Романова (8-я Советская улица) и И.Н. Кораблёва (6-я Советская улица), а также - ряд надгробных памятников на Преображенском еврейском кладбище Санкт-Петербурга [15]. Жизнь Я.Г. Гевирца закончилась трагически - он погиб от истощения во время блокады Ленинграда зимой 1942 года.

«В строительстве синагоги принимали участие харьковские зодчие М.Ф. Пискунов и В.А. Фельдман - автор другого проекта синагоги, получившего вторую премию. Площадь молельного зала в выстроенном здании равнялось 450 кв. м и была рассчитана на 900 мест. Высота купола составляла 42 м, зала - 30 м, длина бокового фасада - 50 м, а общая площадь - более 2000 кв. м. Стиль постройки - романтический модерн, объединяющий романо-готические мотивы со стилизованными башнями, выступами и контрфорсами, с характерным мавританским куполом» $[15 ; 16]$.

После Великой Отечественной войны в этом здании последовательно размещались: еврейский рабочий клуб, детский кинотеатр и спортивное общество «Спартак» (интерьер был реконструирован под спортивный зал).

В 1990 году здание было возвращено еврейской религиозной общине. Проект реставрации был выполнен харьковским филиалом института «Укрпроектреставрация» под руководством архитектора В.Е. Новгородова. Также в этом проекте «принимал участие всемирно известный израильский дизайнер А. Острайхер - автор сотен проектов интерьеров синагог, в том числе и на Украине [17].

«Харьковская хоральная синагога - крупнейшая на территории Украины. Высота купола 42 м, зала - 30 м, крыши - 25 м, длина бокового фасада - 50 м, общая площадь 2067 кв. м. Хранилище свитков синагоги имеет высоту 9 м. В зале площадью 450 кв. м могут разместиться 800-1000 человек» [17]. 
Дмитриев Александр Иванович (1878-1959)

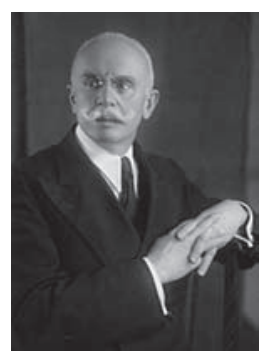

Окончил Институт гражданских инженеров в 1900 году и Академию художеств - в 1903-ем. Работал как архитектор, инженер и архитектурный критик, был автором трудов по строительству инженерных сооружений.

С 1904 году преподавал в Институте гражданских инженеров (ЛИгИ, ЛИИКС, ЛИСИ). Академик архитектуры (1912), действительный член Академии архитектуры (с 1939), доктор архитектуры (с 1947), почётный член Академии архитектуры СССР (c 1956) [18].

В 1912-1913 годы по конкурсному проекту А.И. Дмитриева и Д.С. Ракитина на Привокзальной площади Харькова в стиле неоклассицизма было построено крупномасштабное здание, занимающее целый квартал - Управление Южной железной дороги (рис. 7). В начале 1930-х годов при участии художника Е.Е. Лансере по его же проекту - здание клуба железнодорожников в стиле раннего ар-деко (рис. 8) [19].

В 1929 году А. И. Дмитриев в соавторстве с 0. Р. Мунцем создали проект Дома кооперации, который предполагалось построить северо-восточнее Госпрома. Это было третье из зданий задуманного ранее ансамбля пощади им. Ф.Э. Дзержинского [20].

В этом здании первоначально предполагалось разместить Дом Правительства УССР, но затем оно было отдано Управлению сельского хозяйства. Строительство велось уже не из железобетона, а из кирпича. В 1934 году, после переноса столицы в Киев, недостроенное здание передали Военно-инженерной академии им. Л.А. Говорова (рис. 9). До 1941 года его достроить не успели и закончили лишь в 1954-ом по проекту архитекторов П.Е. Шпары, Н.П. Евтушенко, Н.А. Линецкого, В.И. Дюжина, В.В. Лукьянова и инженера И.М. Гриньв «сталинском стиле», распространившемсяв втовремя.

Первоначально в проектном решении предполагалось создать здание высотой более 20-ти этажей, так как вся композиция из трёх зданий на площади должна была напоминать развёрнутое знамя.

Строительство Дома кооперации было прервано в 1941 году в связи с началом войны. После войны здание было достроено с изменениями и передано Военно-инженерной академии ПВ0 им. маршала Л.А. Говорова. С 2004 году в этом здании находится второй корпус Харьковского национального университета им. В.Н. Каразина.

Проекты А.И. Дмитриева неоднократно публиковались в Ежегоднике Общества архитекторов-художников (1913-1930) [18].

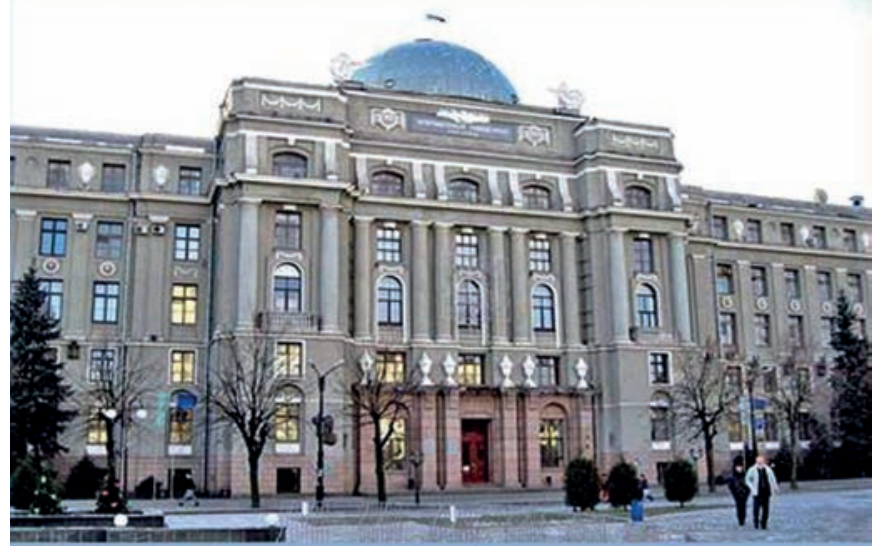

Рис. 7. Здание Управления Южной железной дороги в Харькове. Архитекторы А.И.Дмитриев, Д.С. Ракитин, приучастии инженера В.А. Глазырина, П.П. Роттерта. 1912-1913годы. Фото Т.Ф.Давидич
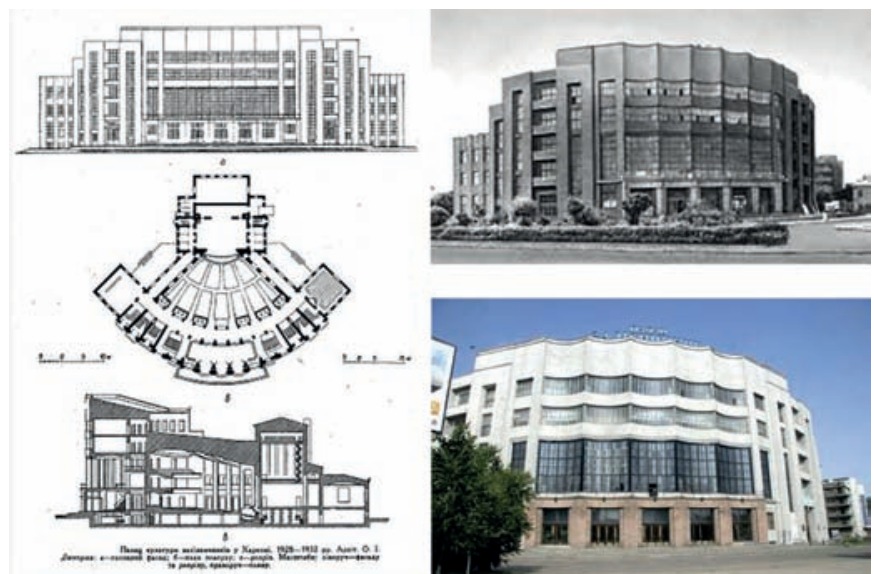

Рис. 8. Дворец культурыжелезнодорожников в Харькове. Архитекторы А.И. Дмитриев, художник Е.Е. Лансере. 1928-1932 годы (источники: http://the-past.inf.ua/list-3-3-4.html и фото Т.Ф. Давидич)
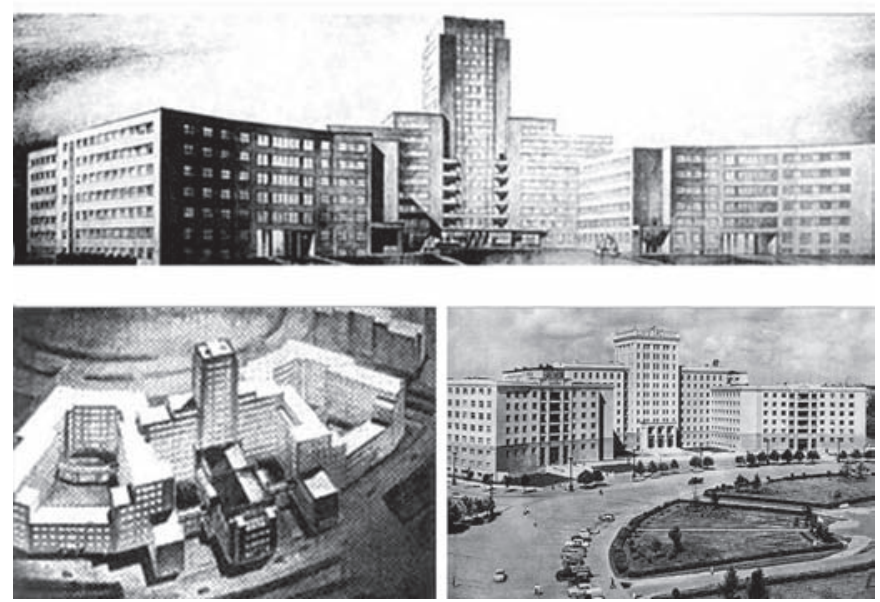

Рис. 9. Дом кооперации в Харькове. Архитектуры А.И. Дмитриев, О.Р. Мунц: а) общий вид, аксонометрия. 1929 год (источники: https://uk.wikipedia.org/wiki; https://ngeorgij.livejournal.com/28559. html); б) здание Военно-инженерной академии им. Л.А. Говорова. Архитекторы П.Е. Шпара, Н.П. Евтушенко, Н.А. Линецкая, В.В. Лукьянов. 1947-1954годы (источник:Харьков сегодня: фотоальбом. - Харьков, Харьковское книжное издательство, 1960. -250с.) 
Мунц Оскар Рудольфович (1871-1942)

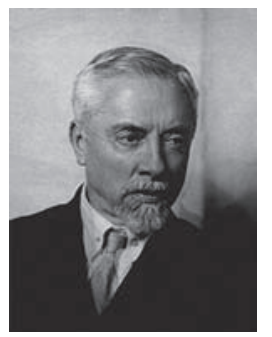

Родился в Одессе в семье генерального консула Нидерландов. В 1889 году переехал в Петербург, в 1893-ем оформил российское подданство. В 1896 году окончил с золотой медалью архитектурное отделение Академии художеств по классу Л.Н. Бенуа, получив право на заграничную командировку. Вернувшись из поездки по Западной Европе, жил в Петербурге и работал помощником у Л.Н. Бенуа. С 1901 года стал работать самостоятельно. После непродолжительного периода увлечения декоративным модерном и стилизациями на русские темы стал приверженцем строгих линий позднего модерна. Строил доходные дома, церкви, особняки и дачи, занимался проектированием интерьеров, создавал также проекты театров и вокзалов. По его проектам были построены здание московского почтамта и Волховская гидроэлектростанция [21].

С 1910-х годов и до конца жизни О.Р. Мунц выступал на страницах профессиональной печати в качестве критика, теоретика и историка архитектуры, редактора и автора статей «Архитектурно-художественного еженедельника» (1914-1917) В теории архитектуры был сторонником структурного рационализма, в котором нераздельно, органически связываются форма и конструкция. В 1910-х годах в своих проектах он тяготел к рационализму и неоклассицизму, ставил своей целью делать форму художественно осмысленной. В 1920-е годы работал над проблемами эстетики в промыш-

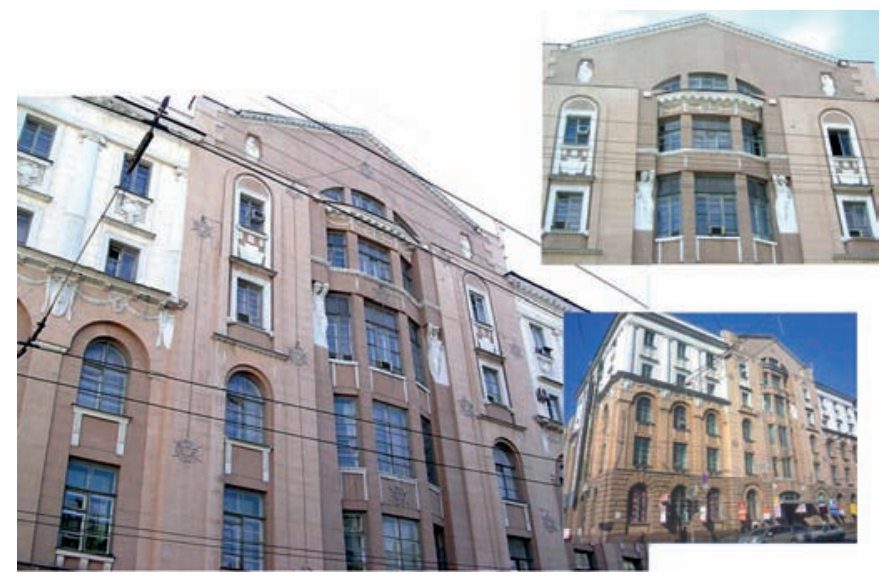

Рис. 10. Здание бывшего Русско-Азиатского (Северного) банка и Женских медицинских курсов. Харьков, Сумская улица, 1. Архитекторы О.Р. Муни, А.К. Шпигель, скульптор В.В. Кузнецов. 1910-е годы. Надстройка-архитектор И.Д. Ермилов. 1926 год. Фото Т.Ф. Давидич ленном и инженерном строительстве и критиковал чистый академизм. Он считал, что работа архитектора не должна сводиться к роли декоратора. Форма должна соответствовать сути конструкции [22].

Во второй половине 1930-х годов в связи с общим изменением в направлении архитектуры, в его творчестве наблюдаются попытки освоения наследия и монументализации форм, схематизированные и упрощённые мотивы ордера (Дворец труда в Сталинграде, заполярный Дом советов в Мурманске). С 1933 года Мунц был руководителем группы, а с 1938-го руководителем мастерской треста «Ленпроект». Последней его работой стал проект дома-бомбоубежища, сделанный в 1941 году Умер 0.Р. Мунц голодной зимой 1942 года во время блокады Ленинграда [23].

В Харькове в 1910-х годах по проекту О.Р. Мунца и А.К. Шпигеля при участии скульптора В.В. Кузнецова было построено здание Русско-Азиатского (Северного) банка и Женских медицинских курсов на углу улицы Сумской, 1 и площади Конституции, в архитектуре которого удачно соединены формы модерна и неоклассицизма, применены железобетонные конструкции (рис. 10). В 1926 году оно было надстроено на два этажа по проекту архитектора И.Д. Ермилова. Это импозантное здание хорошо замыкает собою композицию банковских зданий, созданных по проектам А.Н. Бекетова на бывшей Николаевской площади в самом центре Харькова (ныне - площадь Конституции) и обозначает собой начало главной улицы города - Сумской. Здание было отреставрировано в 1990-е годы по проекту арх. В.М. Лопатько (Харьковский филиал института «Укрпроектреставрация»).

Также 0.Р. Мунц совместно с А.И. Дмитриевым был автором конкурсного проекта Дома Правительства УССР на площади им. Дзержинского (см. рис. 9).

Лидваль Фёдор Иванович (Юхан Фредерик Лидваль) (1870-1945)

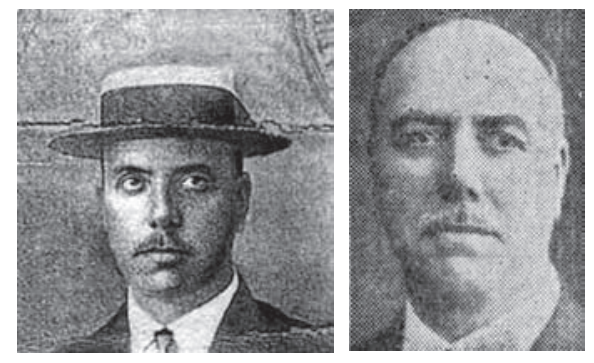

Родился в Санкт-Петербурге в семье портного шведского происхождения. В 1882 году окончил начальную школу при евангелической шведской церкви Святой Екатерины, в 1888 году - Второе петербургское реальное училище. Два года занимался в Училище технического рисования барона Штиглица. В 1896-ом окончил Академию художеств по мастерской Л.Н. Бенуа. В Санкт-Петербурге по его проектам построено более тридцати зданий и сооружений. Наиболее известные 
его постройки: здание Азовско-Донского коммерческого банка (1913, неоклассицизм), доходный дом Н.А. Мельцера (1904-1905. Большая Конюшенная улица, 19-Волынский переулок, 6-8) и доходный дом А.Ф. Циммермана (1907-1914. Каменноостровский проспект, 61 - улица Чаппыгина, 2, модерн). В 1909 году стал академиком архитектуры. В 1910 - 1917 годах преподавал

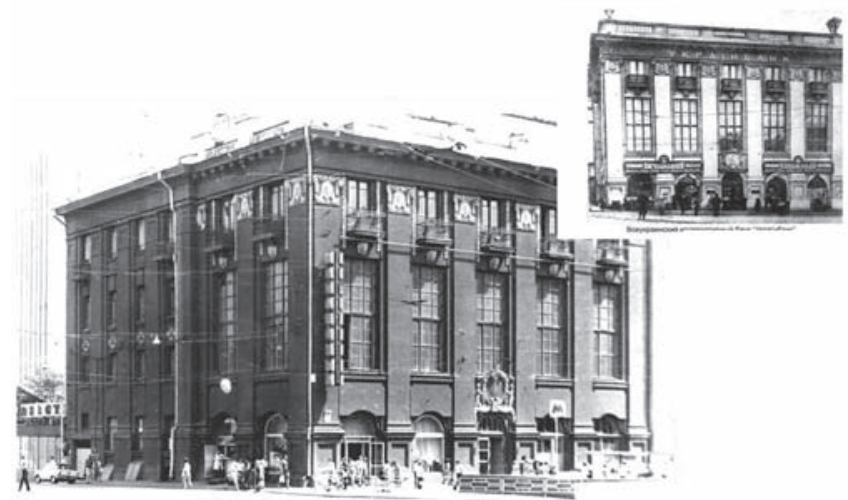

Pис. 11. Здание бывшего Азовско-Донского коммерческого банка. Харьков, площадь Конституции, 18. Архитектор Ф.И. Лидваль (при участии гражданского иженера Л. К. Тервена). 1914 год (источник: https://www.bookersite.com/viewtopic. php?f $=95 \& t=4492 \&$ page $=$ all)

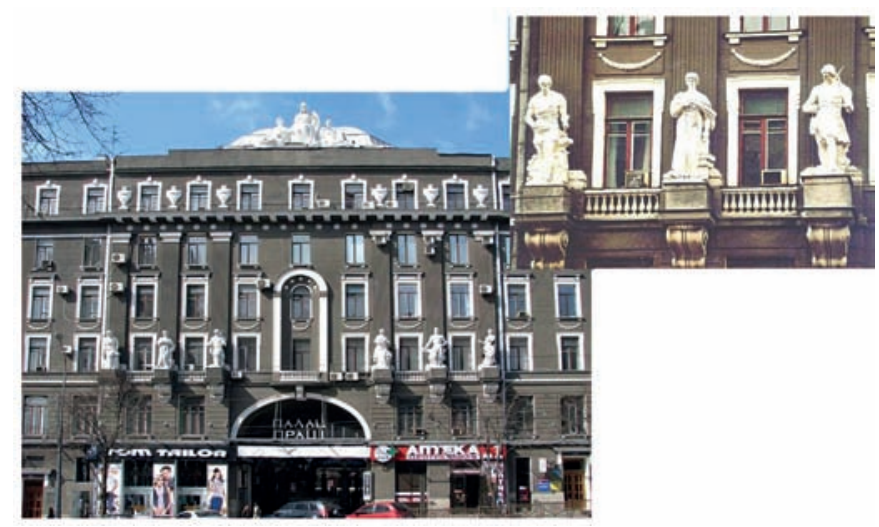

a)

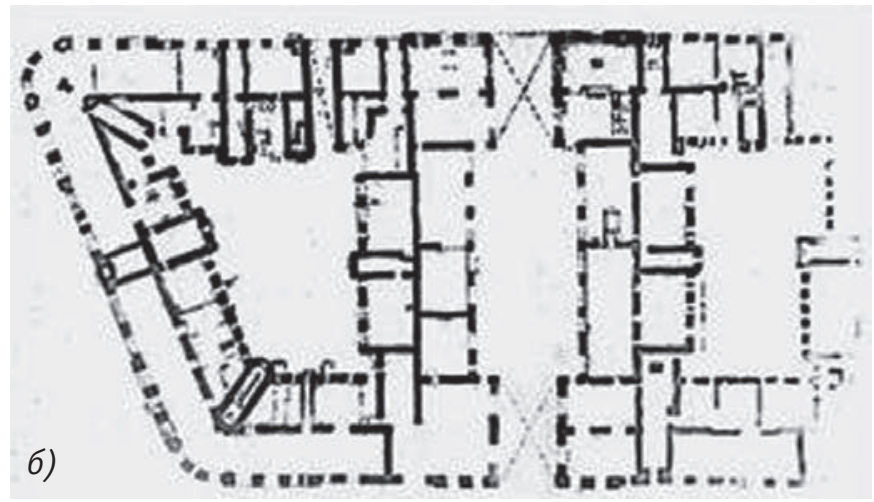

Рис. 12. Бывший доходный дом страхового общества «Россия». Харьков. Архитектор И.А. Претро. 1916 год: а) общий вид. Фото Т.Ф. Давидич; б) план (источник: https:// kh.vgorode.ua/news/sobytyia/115462-na-ploschady-rozyluiksemburh-rubyly-holovy-y-stoialy-menialy) на архитектурном факультете Женского политехнического института. Был членом Петербургского общества архитекторов, принимал участие в издании архитектурно-художественного журнала. Был участником многих архитектурных конкурсов и состоял членом конкурсных комиссий. Ф.И. Лидваль был признанным мастером модерна, построил в этом стиле более тридцати многоэтажных жилых домов в Санкт-Петербурге. Строил он также жилые комплексы, гостиницы и банковские здания, оформлял интерьеры. Некоторые его здания сочетают в своей архитектуре черты модерна и классицизма [25].

В Харькове на Николаевской площади (ныне - площадь Конституции), 18/2 в 1907-1914 годах по его проекту при участии архитектора Л.К. Тервена в формах неоклассицизма с элементами модерна было построено здание АзовскоДонского банка (рис. 11). Ныне здесь находится факультет физического воспитания Харьковского национального педагогического университета им. Г.С. Сковороды.

По его конкурсный проектам (выполненным совместно с Г.А. Косяковым) были построены здания Волжско-Камского банка в Тифлисе (улица Гудиашвили, 7) и Киеве (улица Крещатик, 10), а также (совместно с И.С. Китнером) здание Народного дома в заводском в посёлке Лысьва Пермской губернии.

В 1918 году эмигрировал в Швецию (Стокгольм), где и скончался в 1945 году.

\section{Претро́ Ипполит Александрович (1871-1937)}

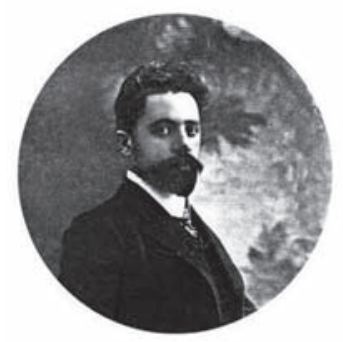

Родился в Санкт-Петербурге в семье железнодорожного служащего, французского подданного Жана Александра Претро и шведской подданной Жезефы Шарлотты Гренмарк. В 1892 году поступил в Императорскую академию Художеств, где завершил образование в мастерской Л.Н. Бенуа. По окончании, в 1901 году, получил звание художника-архитектора и в 1899 году - свидетельство о праве производить постройки. В 1902 году был избран действительным членом Петербургского общества архитекторов. Считается одним из основоположников стилевого течения «Северный модерн». В 1902-1917 годах, наряду с преподавательской и архитектурной деятельностью в приюте принца Ольденбургского и других благотворительных учреждениях, имел обширную проектную и строительную частную практику. В 1920-х - 1930-х годах занимал должность главного архитектора-художника архитектурной мастерской ЛенИ30, был профессором Академии художеств. Имел реализации проектов различных зданий и комплексов в Ленинграде, Перми, Новосибирске, Запорожье [26]. 
К великому сожалению, архитектор И.А. Претро пал жертвой политических репрессий - в октябре 1937 года был арестован Комиссией НКВД и Прокуратуры СССР по «делу РОВС». В декабре 1937 года был приговорён по статье 58-68-11 УК РСФСР к расстрелу.

В Харькове по его проекту в формах неоклассицизма был построен доходный дом страхового общества «Россия» на площади Конституции (бывшей Николаевской, Тевелева), 1 (1914-1916). Во времена СССР имел название «Дворец Труда». Ныне - памятник архитектуры местного значения (рис. 12).

За пятнадцать лет, предшествовавших революции 1917 года, по его проектам в Санкт-Петербурге было построено около сорока зданий. И. А. Претро считается одним из ведущих мастеров северного модерна (в одном ряду с такими архитекторами как Н.В. Васильев, А.Ф. Бубырь, Ф.И. Лидваль). Наиболее удачные его постройки: дом № 54 на 3-й линии и № 48 на 11-й линии Васильевского острова, дома на проспекте Огородникова, 35, на Большом проспекте, 44. В 1907 году на городском конкурсе лучших фасадов был отмечен премией и серебряной медалью [27].

\section{Ржепишевский Александр Иванович (1879-1930)}

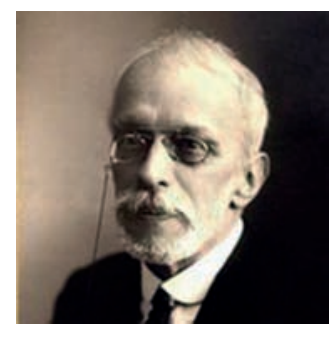

Родился в городе Аккерман (Белгород-Днестровский) Бессарабской губернии в семье военнослужащего пограничных войск. После окончания гимназии в Одессе поступил в институт Гражданских инженеров в Санкт-Петербурге, который закончил с золотой медалью в 1903 году. Получил право на стажировку в университете Сорбонна (Париж, 1904-1906). В 1908-1910 годы жил в Санкт-Петербург, зарабатывал на жизнь составлением конкурсных проектов. Известны несколько его совместных проектов с Николаем Васильевым, один из которых - здание Харьковского городского купеческого банка (2-я премия), был принят к постройке. В 1910 году принял предложение переехать в Харьков для ведения авторского надзора на строительстве банка. Одновременно с этим исполнял обязанности внештатного городского архитектора. На волне строительного бума в Харькове получил большое количество частных заказов, открыл собственную мастерскую. По проектам Александра Ржепишевского до революции были построены ряд доходных домов, особняков, общественных и промышленных зданий всего 27 построек. С 1910-го по 1920 год работал в Харькове Принимал активное участие в архитектурных конкурсах, был

1 Русский Общевоинский Союз - организация, созданная в 1924 году бароном П. Врангелем в среде белой эмиграции. членом архитектурно-строительного отдела Харьковского технического общества, основанного в 1904 году. После революции переехал в Москву, где скоропостижно скончался в возрасте 51 года в результате инсульта. Один из выдающихся мастеров стиля модерн в его западноевропейском варианте. 27 зданий, построенных по его проектам в Харькове, значительно обогатили центральную часть города.

На месте здания гостиницы «Астория» и Купеческого банка располагался дом купца Ломакина, построенный в начале XIX века по проекту архитектора П.А. Ярославского. Со второй половины XIX века его занимал старейший банк Харькова - Городской купеческий Банк на Торговой площади. В 1908 году этот дом признали аварийным и снесли. Был объявлен всероссийский конкурс на проект нового здания. На первом этаже было решено разместить банк и магазины, на втором и третьем - конторы для сдачи внаём разным организациям, а на трёх верхних - гостиницу «Астория». Победил в конкурсе проект молодых архитекторов из Санкт-Петербурга - Н.В. Васильева и А.И. Ржепишевского. В 1910-1913 годы здание было построено. Оно стало одним из первых зданий Харькова с железобетонным каркасом. А.И. Ржепишевский после окончания строительства остался в Харькове, где был одним из самых популярных архитекторов. Всего до революции 1917 года в Харькове по проектам Александра Ивановича было построено 27 домов, двадцать из которых признаны памятниками архитектуры [28; 29].

Наиболее значительные постройки по проектам А.И. Ржепишевского в Харькове: торгово-складское здание купца Миндовского на улице Рождественской, 6 (1910); торговый дом купца Бакакина на улице Рождественской, 17 (1910); Компанейский дом на улице Рымарской, 9 (1912); особняк театрального режиссёра Н.Н. Синельникова на улице Дарвина, 29 (1913); доходный дом товарищества «М. Гельферих-Саде» на улице Маршала Бажанова, 14 (1910-1913) (рис. 13); кооперативный жилой дом-комплекс на улице Рымарской, 9 (1912-1914), в котором жил сам автор; дом

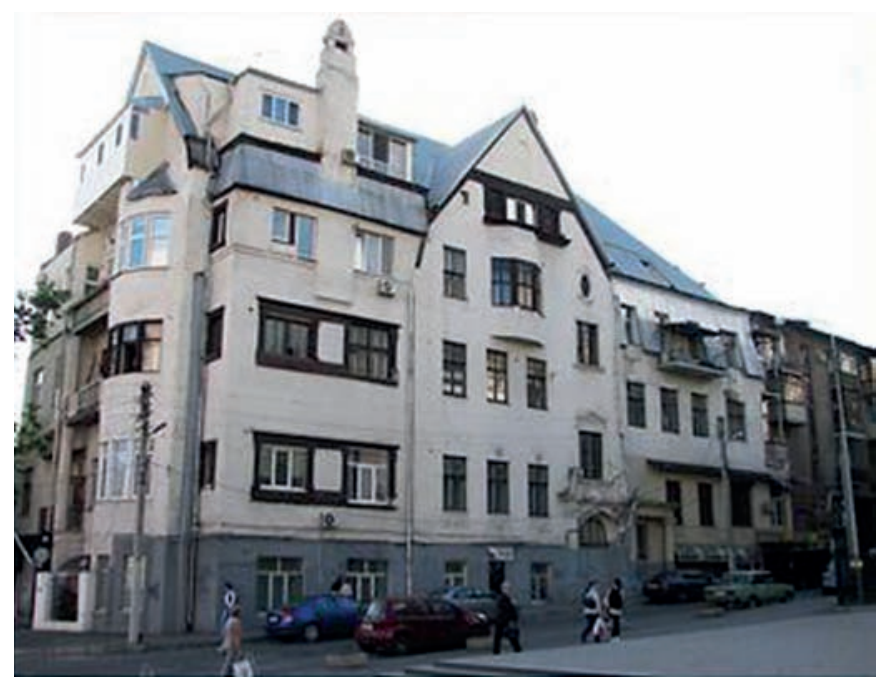

Рис. 13. Бывший доходный дом товарищества «ГельферихСаде». Харьков, улица Бажанова. Архитектор А.И. Ржепишевский. 1910-1913 годы. Фото Т.Ф. Давидич 
купца Молдавского (в соавторстве с И. Тенне) на улице Дарвина, 4; жилой дом на улице Юлия Чигирина, 8; здание больницы Красного Креста на площади Фейербаха, 5.

\section{Серафимов Сергей Саввич (1878-1939)}

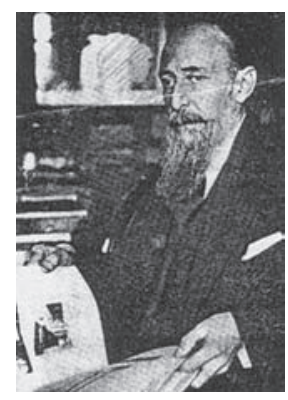

С 1930 года около тридцати республиканских трестов переехали в Харьков - тогдашнюю столицу Советской Украины и расположились в разных приспособленных зданиях, часто неблагоустроенных. Они образовали паевое товарищество для строительства специального здания - Дома Государственной промышленности, место для которого было выбрано на новой главной площади Харькова («круглой»), где должен был сформирован правительственный центр УССР. 21 марта 1925 года Высшим Советом народного хозяйства был объявлен конкурс на разработку проекта этого здания нового типа, соответствующего новым задачам социалистического строительства. Здание предполагалось включить в радиальнокольцевую систему новой площади, создаваемой по эскизу архитектора В. К. Троценко (рис. 14).

Через три месяца на суд жюри было представлено 17 проектов. Первая премия была присуждена проекту под девизом «Незваный гость», авторами которого были ленинградцы С.С. Серафимов, С.М. Кравец, М.Д. Фельгер.

Сергей Саввич Серафимов был уроженцем города Трапезунда. Окончил художественное училище в Одессе, затем, в 1910 году - Петербургскую академию художеств. Проектировал доходные дома, банки, вокзалы Бухарской железной дороги в стиле неоренессанса и «елизаветинского» псевдо-
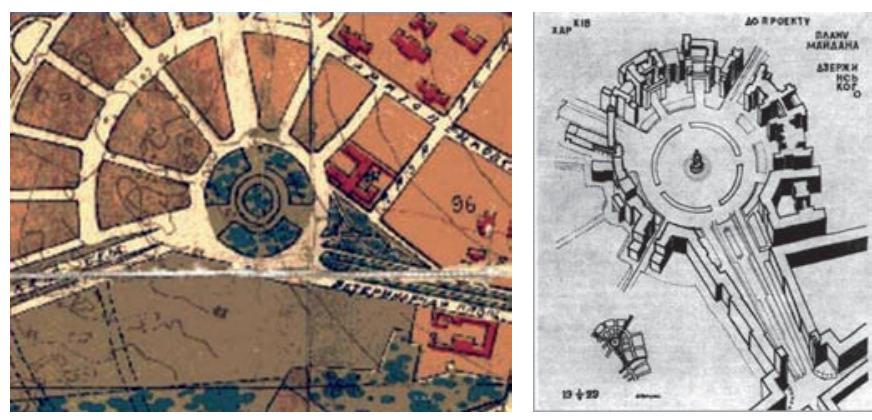

Рис. 14. Идеи создания и дальнейшего развития ансамбля площади им. Дзержинского - нового общественного центра Харькова как столицы УССР. Архитектор В.К. Троценко. 1923-1929 годы (источник: https://bekalo.livejournal. com/70060.html) барокко. После революции преподавал в Петроградских государственных свободных художественных учебных мастерских (ПГСХМ), затем - в Высшем художественно-техническом институте (ВХУТЕИН), далее - в ЛВХТИ (после реорганизации с 1934 года - ИЖСА). Занимал должность проректора по учебной части [30; 31]. Всемирная слава ждала его в Харькове, где он со своими соавторами реализовал конкурсный проект, ставший впоследствии символом этого города.

0 своём проектном решении здания Госпрома С.С. Серафимов писал: «Дом Госпромышленности я пытался решить как частицу организованного мира, показать фабрику, завод, ставший дворцом».

В этом здании сосредоточилось до тридцати самостоятельных учреждений с общим залом собраний, столовой, библиотекой. Композиция его строилась по принципу осевой симметрии, но центральная часть была контрастно понижена. Сложная композиция разновысоких объёмов Госпрома как бы пронизывается пространством и включается органически в композицию площади. Интересно, что в пространственном восприятии симметрия, необходимая для уравновешивания объёма, практически исчезает.

Конкурсный проект, принятый к реализации в июне 1925 года, разрабатывался в рабочих чертежах ударными темпами. В специально построенном деревянном бараке работали молодые архитекторы - студенты и выпускники Харьковского технологического института. Многие прошли здесь хорошую практическую школу. Здание по величине и сложности конструктивного решения в то время не имело аналогов в СССР и в Европе. В его конструкции были применены многоярусные и многопролётные рамные железобетонные конструкции, методы расчёта которых только предстояло разработать в процессе проектирования. Многие сложные инженерные задачи были решены специально созданным конструкторским бюро во главе с инженером М.А. Рудником. По итогам работы в 1929 году была издана книга по методике расчёта сложных статически неопределимых рамных систем (авторы: А.В. Прейсфрейнд, М.М. Пайков). Начальником строительства был назначен опытный инженер П.П. Роттерт (1880-1957, также выпускник ПИГИ. Он привлекал к работе, в основном, творческую молодёжь не старше тридцати лет.

Проектное обеспечение, как видно, оказалось отличным, чего нельзя сказать о техническом обеспечении строительства. Через восемь лет после революции гигантское здание - самый большой тогда в Европе «небоскрёб» объёмом в 347000 куб. м из монолитного железобетона - пришлось строить при помощи человеческой и лошадиной энергии, «умноженной» на мощность лопат, носилок, тачек и прочей подобной техники. 5000 рабочих трудились в три смены и совершили чудо, которое можно объяснить только комсомольским энтузиазмом: строительство столь гигантского здания было завершено за 2,5 рабочих сезона (!). На него ушло: 1315 вагонов цемента, 9000 т металла, 3700 вагонов гранита, 40000 кв. м стекла. Трудозатраты составили 1 млн 560 тыс. чел.-дней, сметная стоимость строительства - 9 млн 50 тыс. рублей [32; 33]. 
Конечно, собранных трестами денежных средств не хватило. Остальные деньги помог добыть Ф.Э. Дзержинский: по его предложению правительство приняло решение о внеочередном финансировании строительства. Поэтому, после скоропостижной смерти Ф. Э. Дзержинского в 1926 году Госпрому и площади было присвоено его имя. К 10-летию революции была завершена первая очередь строительства, а в ноябре 1928 года. здание было полностью готово: в него въехали тресты «Коксобензол», «Химуголь», «Югосталь», металлургические, химические и машиностроительные управления.

Строительство Госпрома (рис. 15) стало началом формирования ансамбля этой площади. В конце 1920-х - начале 1930-х годов проводится ряд конкурсов на разработку планировочного решения и дальнейшей застройки площади. В первую очередь намечено строительство двух крупных зданий по обеим сторонам от Госпрома: Дома проектных организаций и Дома кооперации.

В конце 1920-х - начале 1930-х годов проводится ряд конкурсов на разработку планировочного решения и дальнейшей застройки площади. В первую очередь намечено строительство двух крупных зданий по обеим сторонам от Госпрома: Дома Проектных организаций и Дома Кооперации.

В конкурсе на здание Дома проектов (который сначала предполагалось строить для Дома правительства УССР) снова одержал победу С.С. Серафимов в соавторстве с М.А. Зандберг-

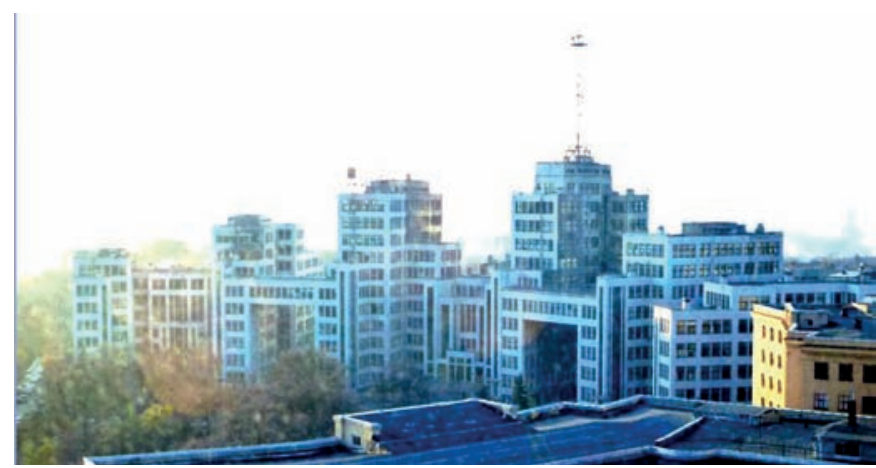

Рис. 15. Дом государственной промышленности (Госпром). Харьков. Архитекторы С.С. Серафимов, С.М. Кравеи, М.Д. Фельгер, инженер П.П. Роттерт. 1925-1928 годы. Фото Т.Ф. Давидич

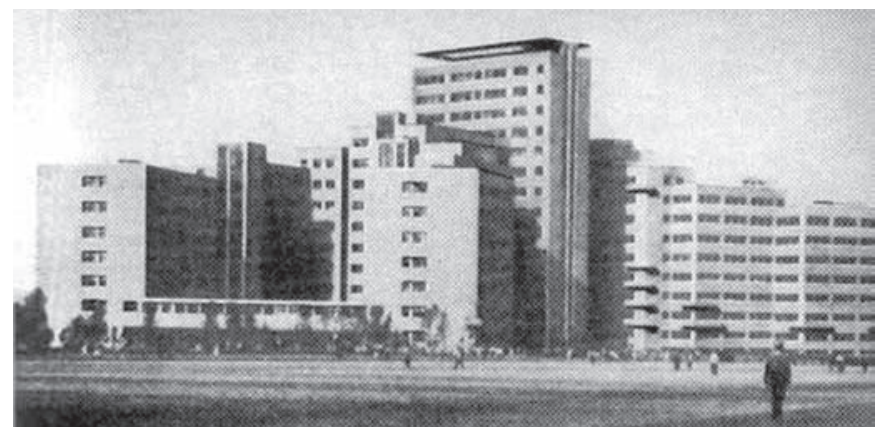

Рис. 16. Дом проектных организаций (первоначально - Дом Правительства Украинской ССР). Архитекторы С.С. Серафимов, М.А. Зандберг-Серафимов. 1927 год (источник: https:// sfw.so/index.php?newsid=1148783049).
Серафимовой. Это здание также было задумано строить из монолитного железобетона, но в целях экономии перекрытия через этаж были устроены по деревянным балкам. Поэтому во время войны оно сильно пострадало и было реконструировано по проекту архитекторов В.П. Костенко, В.И. Лифшица, инженеров 0. Иванченко, В. Дудника под новое здание Харьковского Национального университета им. В.Н. Каразина (рис. 16).

В результате этой реконструкции здание полностью лишилось своей первоначальной стилистики и объёмно-пространственной пластики. Многие архитекторы считают, что решение Дома проектных организаций удалось авторам значительно лучше, чем здание Госпрома, так как в его формах уже более отчётливо проявились черты изящного стиля ар-деко. Его детали более тонко проработаны, формы построены на контрасте центральной высотной доминанты, подчёркнутой вертикальными щелями остекления и пространственных «крыльев», в которых преобладают горизонтальные членения. Контраст глухих и остеклённых поверхностей, завершение центрального корпуса в виде плоской «парящей» плиты, вертикальные и горизонтальные сквозные просветы, пропускающие лучи солнца на фасаде, ориентированном на север в местах примыкания боковых частей к центральной - всё это было утрачено навсегда.

\section{Кравец Самуил Миронович (1891-1966).}
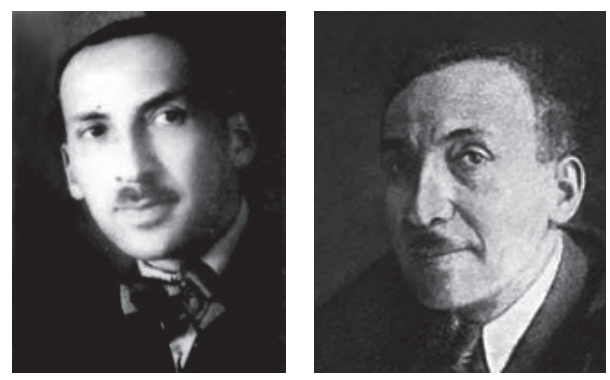

Соавтор С.С. Серафимова - С.М. Кравец, родился в городе Вильно (Вильнюсе), окончил Академию художеств в Петрограде в 1917 году и Второй политехнический институт там же (1922). Работал в мастерской академика архитектуры И.А. Фомина. В процессе реализации проекта Госпрома он остался в Харькове для руководства разработкой рабочих чертежей. Был также автором проекта здания Химического корпуса старого университета (ныне - один из корпусов УИПА по улице Университетской) (рис. 17).

Также С.М. Кравец принимал участие в конкурсе на проект Дома правительства в Харькове (1927, соавтор И.Ф. Милинис). В 1930 году был командирован в США, где выполнил эскизный проект главного корпуса Харьковского турбинного завода. С середины 1930-х годов жил и работал в Москве, был главным архитектором Метропроекта. Стал автором проектов нескольких станций Московского метрополитена. Имел ряд публикаций в архитектурной прессе.

Реализованные проекты С.М. Кравца в Москве: наземный павильон станции метро «Дворец Советов» (1935; с октября 
1957-го - «Кропоткинская»); станция метро «Сталинская» (1938, скульпторы В.И. Мухина, В.И. Венцель) открыта в 1944 году; жиилой дом Метростроя с встроенными вестибюлями станции метро «Аэропорт» по адресу Ленинградский пр-т, 64 (1938; 1950-1954, при участии И.Д. Мельчакова).

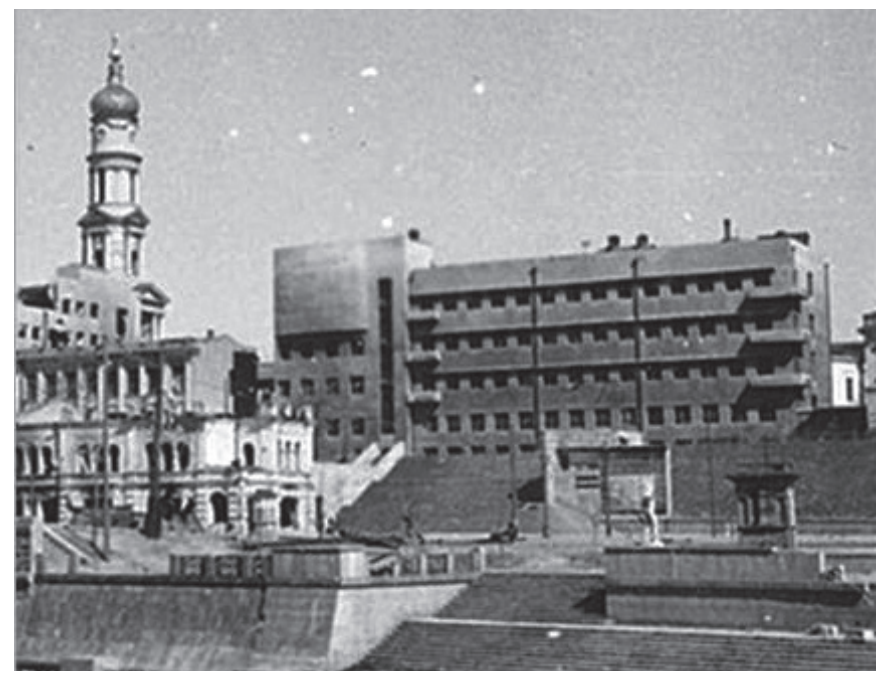

Рис. 17. Химический корпус УзПИ. Харьков, улица Университетская. Архитектор С.М. Кравец. 1930 год

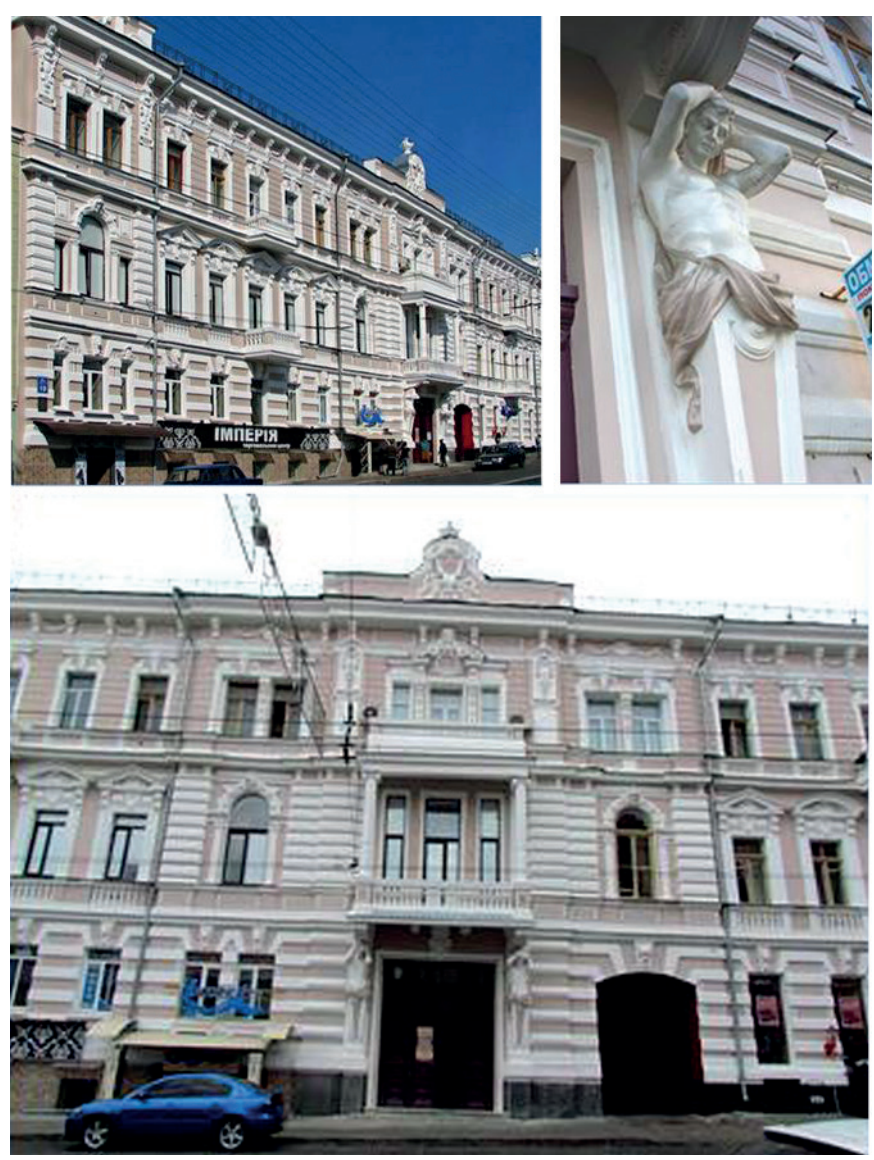

Рис. 18. Бывший доходный дом страхового общества «Жизнь». Харьков, улица Сумская, 19. Архитектор Н.А. Штакеншнейдер. Конец 1890-х годов
Штакеншнейдер Николай Андреевич (1839 - неизвестно) Учился в ИАХ в 1859-1865 годах.

Сын известного придворного архитектора Андрея Штакеншнейдера, автора первого императорского дворца в Ореанде, возведённого в 1852 году при императоре Николае I. Был автором ряда построек на Ялтинской набережной и в Ливадии. В 1887 году выехал в Петербург [5].

\section{Лumepamypa}

1. Ясієвич В.Є. Київський зодчий П. Ф. Альошин / Киев : Будівельник, 1966.

2. П.Ф. Алёшин [Электронный ресурс] // Википедия. Режим доступа: https://ru.wikipedia.org/wiki/Алёшин,_Павел_Федотович (дата обращения 01.06.2020).

3. Альошин Павло Федотович [Электронный ресурс] // Енциклопедія сучасноі України. - Режим доступа: http://esu.com. ua/search_articles.php?id=43913 (дата обращения 01.06.2020).

4. Посёлок ХТЗ [Электронный ресурс] // Википедия. Режим доступа: https://ru.wikipedia.org/wiki/Посёлок_ХТ3 (дата обращения 03.06.2020).

5. Соцгорода планеты СССР : справочная статья к циклу «Плывущий город (заметки по поводу исторических памятников Норильского региона)» // Всемирная энциклопедия путешествий. - Режим доступа: https://planetguide.ru/ academy/entry/480/ (дата обращения 02.06.2020).

6. Проектирование и строительство соцгорода «Новый Харьков» [Электронный ресурс] // Архитектор Павел Алёшин. Страницы жизни и творчества. - Режим доступа: http://www. alyoshin.ru/Files/gradostr/htz.html (дата обращения 05.06.2020).

7. Зодчие Санкт-Петербурга. XIX - начало XX века / сост. В.Г. Исаченко; ред. Ю. Артемьева, С. Прохватилова. - СПб : Лениздат, 1998. - С. 843-861.

8. Лисовский, В.Г. Николай Васильев. Алексей Бубырь / В.Г. Лисовский, В.Г. Исаченко; Предисл. Н.И. Явейна. - СПб : Белое и Чёрное, 1999. - 287 с.

9. Лисовский, В.Г. Николай Васильев. От модерна к модернизму / В.Г. Лисовский, Р. М. Гашо. - М. : Коло, 2011. - 464 С.

10. Давидич Т.Ф. Особенности творчества архитектора Николая Васильева (1875-1958) [Электронный ресурс] / Т. Ф. Давидич, И. Н. Лаврентьев, В. М. Лопатько // Науковий вісник будівництва. - 2017. - Т. 89. - № 3. - С. 15-28. - Режим доступа: http://nbuv.gov.ua/UJRN/Nvb_2017_89_3_5 (дата обращения 07.07.2020).

11. Архитекторы-строители Петербурга-Петрограда начала XX века : Каталог выставки. - Л. : Всероссийское общество охраны памятников истории и культуры. Ленинградское отделение, 1982. - 170 с.

12. Архитектор Верёвкин Н.Н. [Электронный ресурс] // Citywalls. Архитектурный сайт Санкт-Петербурга. - Режим доступа: http://www.citywalls.ru/search-architect3114.html (дата обращения 10.07.2020).

13. К истории харьковского дома страхового общества «Саламандра» [Электронный ресурс] // Харьков : обзор статей 
и страниц краеведческого альбома. - Режим доступа: http:// the-past.inf.ua/list-3-3-16.html (дата обращения 10.07.2020).

14. Петербургский архитектор Я.Г. Гевирц [Электронный ресурс] // Музеи России. Новости музеев. - Режим доступа: http://www.museum.ru/N18363 (дата обращения 15.07.2020).

15. Харьковские синагоги [Электронный ресурс] // Харьков : обзор статей и страниц краеведческого альбома. Режим доступа: http://the-past.inf.ua/list-2-1-45.html (дата обращения 10.07.2020).

16. Койфман, В. Архитектор Санкт-Петербурга Яков Гевирц. 1879-1942 [Электронный ресурс] // Проза. Ру. - Режим доступа: https://proza.ru/2018/10/17/462 (дата обращения 11.07.2020).

17. Харьковская хоральная синагога [Электронный ресурс] // Википедия. Режим доступа: https://ru.wikipedia.org/wiki/ Харьковская_хоральная_синагога (дата обращения 09.07.2020).

18. Кириков, Б.М. Александр Дмитриев. Архитектор первой половины XX века / Б.М. Кириков. - СПб : Коло, 2009. - 400с.

19. Кириков, Б. М. Архитектор А.И. Дмитриев (к 100-летию со дня рождения) / Б.М. Кириков // Архитектура СССР. - 1979. - № 2. - С. 31-34.

20. Кириков, Б.М.Поиски нового в творчестве архитектора А.И. Дмитриева (период 1900-1917 гг.) / Б.М. Кириков // Архитектурное наследство. - 1979. - № 27. - С. 180-189.

21. Кириков, Б.М. А. И. Дмитриев и его вклад в развитие архитектуры 1920-х гг. / Б.М. Кириков // Поиски стиля. - М., 1994 г. - С. 77-84.

22. Кириков, Б.М. Александр Дмитриев / Б,М. Кириков. СПб : Белое и чёрное, 2004. - 446 с.

23. Мунц Оскар Рудольфович [Электронный ресурс] // Totalarch. - Режим доступа: http://famous.totalarch.com/ munz (дата обращения 15.07.2020).

24. Мастера советской архитектуры об архитектуре : Избранные отрывки из писем, статей, выступлений и трактатов : В 2 т. / Под общ. ред. М. Г. Бархина [и др.]. - М. : Искусство, 1975.

25. Хроника [Электронный ресурс] // Архитектура Ленинграда. - 1939. - № 2. - С. 76-77.

26. Архитекторы-строители Санкт-Петербурга середины XIX - начала XX века : Справочник / Авторы-сост. Гинзбург А.М., Кириков Б.М. - СПб : Пилигрим, 1996. - С. 223-224.

27. Зодчие Санкт-Петербурга. XX век. - СПб : Лениздат, 2000. - С. 30-42.

28. Лидваль Фёдор Иванович // Википедия. - Режим доступа: https://ru.wikipedia.org (дата обращения 13.07.2020).

29. Оль, А.А. Ф.И. Лидваль / А.А. Оль. - СПб, 1914.

30. Лисовский, В.Г. Мастера петербургского модерна. Страницы творческой биографии Ф.И. Лидваля // Строительство и архитектура Ленинграда. - 1980. - № 3.

31. Претро Ипполит Александрович [Электронный ресурс] // Википедия. - Режим доступа: https://ru.wikipedia.org/wiki/ Претро,_Ипполит_Александрович (дата обращения 16.07.2020).

32. Претро Ипполит Александрович [Электронный ресурс] // ДелоРус. - Режим доступа: http://delorus.com/ medialibrary/detail.php?ID=1926 (дата обращения 17.07.2020).
33. Исаченко, В.Г. Ипполит Претро [Электронный ресурс] / В.Г. Исаченко // ВикиЧтение. - Режим доступа: https:// design.wikireading.ru/13694 (дата обращения 25.06.2020).

34. Архитектор Ржепишевский [Электронный ресурс]. Режим доступа: https://old-akkerman.livejournal.com/10731. html (дата обращения 28.06.2020).

35. Ржепишевский Александр Иванович [Электронный ресурс] // Википедия. - Режим доступа: https://ru.wikipedia. org/wiki/Ржепишевский,Александр_Иванович (дата обращения 16.06.2020).

36. Полякова, Ю.Ю. Архитекторы Харькова польского происхождения / Ю.Ю. Полякова // Польська діаспора у Харкові: історія та сучасність : Матеріали наук. конф., м. Харків, 24 квіт. 2004 р. - Харьков : Майдан, 2004. - С. 111-124.

37. Серафимов Сергей Саввич // Википедия. - Режим доступа: https://ru.wikipedia.org/wiki/Серафимов,_Сергей_Саввич (дапта обращения 19.07.2020).

38. Серафимов Сергей Саввич (1878-1939) [Электронный ресурс]//Трамвай искусств. - Режим доступа https://tramvaiiskusstv. ru/grafika/spisok-khudozhnikov/item/2092-serafimovsergej-savvich-1878-1939.html (дата обращения 28.07.2020).

39. Ежегодник Общества архитекторов-художников. 1927. - Вып. 12. - С. 109-122.

40. Ежегодник Общества архитекторов-художников. 1930. - Вып. 13. - С. 96- 97.

41. Некролог // Архитектура СССР. - 1940. - № 1. - С. 74.

42. Памятники архитектуры и истории Санкт-Петербурга. Василеостровский район. - СПб : Коло, 2006. - С. 445-446.

43. Лейбфрейд, А.Ю. Харьков. От крепости до столицы : заметки о старом городе / А. Лейбфрейд, Ю. Полякова. Харьков : Фолио, 2004. - С. 116-118.

44. Давидич, Т.Ф. Площадь им. Дзержинского, ГОСПРОМ и харьковский конструктивизм [Электронный ресурс] // Харьков. Официальный сайт. - Режим доступа: https://www. kharkov.ua/culture/2b.html (дата обращения 29.07.2020).

45. Кравец Самуил Миронович [Электронный ресурс] // Википедия. - Режим доступа: https://ru.wikipedia.org/wiki/ Кравец,_Самуил_Миронович (дата обращения 22.07.2020).

\section{References}

1. Yasievich V.€. Kï̈vs'kii zodchii P.F. Al'oshin [Kiev architect P.F. Aleshin]. Kiev, Budivel'nik Publ., 1966.

2. P. F. Aleshin. In: Vikipediya [Wikipedia]. Access mode: https://ru.wikipedia.org/wiki/Aleshin,_Pavel_Fedotovich (accessed 06.01.2020).

3. Al'oshin Pavlo Fedotovich. In: Entsiklopediya suchasnoi Ukraïni [Encyclopedia of Modern Ukraine]. Access mode: http:// esu.com.ua/search_articles.php?id=43913 (accessed 06.01.2020).

4. Poselok KhTZ [Settlement KhTZ]. In: Vikipediya [Wikipedia]. Access mode: https://ru.wikipedia.org/wiki/ Poselok_KhTZ (accessed 06.03.2020).

5. Sotsgoroda planety SSSR : spravochnaya stat'ya k tsiklu «Plyvushchii gorod (zametki po povodu istoricheskikh 
pamyatnikov Noril'skogo regiona)» [Social cities of the planet of the USSR: reference article to the cycle "Floating city (notes on the historical monuments of the Norilsk region)"]. In: Vsemirnaya entsiklopediya puteshestvii [Social cities of the planet of the USSR: reference article to the cycle "Floating city (notes on the historical monuments of the Norilsk region)"]. Access mode: https://planetguide.ru/academy/entry/480/ (accessed 026.02.2020).

6. Proektirovanie i stroitel'stvo sotsgoroda «Novyi Khar'kov» [Design and construction of the social city "New Kharkov"]. In: Arkhitektor Pavel Aleshin. Stranitsy zhizni i tvorchestva [Architect Pavel Alyoshin. Pages of life and creativity]. Access mode: http://www.alyoshin.ru/Files/gradostr/htz.html (accessed 06.05.2020).

7. Zodchie Sankt-Peterburga. XIX - nachalo XX veka [Architects of St. Petersburg. XIX - early XX century], V.G. Isachenko (comp.); Yu. Artemyeva, S. Prokhvatilova (eds.). Saint Petersburg, Lenizdat Publ., 1998, pp. 843-861.

8. Lisovskii V.G., Isachenko V.G. Vasil'ev N. Aleksei Bubyr' [Vasiliev N. Alexey Bubyr]. Saint Petersburg, White and Black Publ., 1999, 287 p.

9. Lisovskii V.G., Gasho R.M. Nikolai Vasil'ev. Ot moderna k modernizmu [Nikolay Vasiliev. From modern to modernism]. Moscow, Kolo Publ., 2011, 464 p.

10. Davidich T.F., Lavrent'ev I.N., Lopat'ko V.M. Osobennosti tvorchestva arkhitektora Nikolaya Vasil'eva (1875-1958) [Features of the creative work of the architect Nikolai Vasiliev (1875-1958)]. In: Naukovii visnik budivnitstva [Scientific Bulletin of Construction], 2017, Vol. 89, no. 3, pp. 15-28. Access mode: http://nbuv.gov.ua/UJRN/Nvb_2017_89_3_5 (accessed 07.07.2020).

11. Arkhitektory-stroiteli Peterburga-Petrograda nachala XX veka : Katalog vystavki [Architects-builders of St. PetersburgPetrograd at the beginning of the XX century: Exhibition catalog]. Leningrad, All-Russian Society for the Protection of Historical and Cultural Monuments. Leningrad branch, 1982, 170 p.

12. Arkhitektor Verevkin N.N. [Architect Verevkin N.N.]. In: Citywalls. Arkhitepktuprnyi sait Sankt-Peterburga [Citywalls. Architectural site of St. Petersburg]. Access mode: http://www. citywalls.ru/search-architect3114.html (accessed 07.10.2020).

13. $K$ istorii khar'kovskogo doma strakhovogo obshchestva «Salamandra» [To the history of the Kharkov house of the insurance company "Salamandra"]. In: Khar'kov : obzor statei i stranitsi kraevedcheskogo al'boma [Kharkov: review of articles and pages of the local history album]. Access mode: http://thepast.inf.ua/list-3-3-16.html (accessed 07.10.2020).

14. Peterburgskii arkhitektor Ya.G. Gevirts [Petersburg architect Ya.G. Gevirtz]. In: Muzei Rossii. Novosti muzeev [Petersburg architect Ya.G. Gevirtz]. Access mode: http://www. museum.ru/N18363 (accessed 07.15.2020).

15. Khar'kovskie sinagogi [Kharkov synagogues]. In: Khar'kov : obzor statei i stranitsi kraevedcheskogo al'boma [Kharkov: review of articles and pages of the local history album].
Access mode: http://the-past.inf.ua/list-2-1-45.html (accessed 07.10.2020).

16. Koifman V. Arkhitektor Sankt-Peterburga Yakov Gevirts. 1879-1942 [Architect of St. Petersburg Yakov Gevirtz. 1879-1942]. In: Proza. Ru. Access mode: https://proza. ru/2018/10/17/462 (accessed 07.11.2020).

17. Khar'kovskaya khoral'naya sinagoga [Kharkov Choral Synagogue]. In: Vikipediya [Wikipedia]. Access mode: https:// ru.wikipedia.org/wiki/Khar'kovskaya_khoral'naya_sinagoga (accessed 07.09.2020).

18. Kirikov B.M. Aleksandr Dmitriev. Arkhitektor pervoi poloviny XX veka [Alexander Dmitriev. Architect of the first half of the XX century]. Saint Petersburg, Kolo Publ., 2009, 400 p.

19. Kirikov B. M. Arkhitektor A.I. Dmitriev (k 100-letiyu so dnya rozhdeniya) [Architect A.I. Dmitriev (to the 100th anniversary of his birth)]. In: Arkhitektura SSSR [Architecture of the USSR], 1979, no. 2, pp. 31-34.

20. Kirikov B. M Poiski novogo v tvorchestve arkhitektora A.I. Dmitrieva (period 1900-1917 gg.) [The search for something new in the work of the architect A.I. Dmitrieva (period 19001917)]. In: Arkhitekturnoe nasledstvo [Architectural heritage], 1979, no. 27, pp. 180-189.

21. Kirikov B.M. A.I. Dmitriev i ego vklad v razvitie arkhitektury 1920-kh gg. [A.I. Dmitriev and his contribution to the development of architecture in the 1920s]. In: Poiski stilya [Search for style]. Moscow, 1994, pp. 77-84.

22. Kirikov B. M. Aleksandr Dmitriev. Saint Petersburg, White and Black Publ., 2004, 446 p.

23. Munts Oskar Rudol'fovich. In: Totalarch. Access mode: http://famous.totalarch.com/munz (accessed 07.15.2020).

24. Mastera sovetskoi arkhitektury ob arkhitekture : Izbrannye otryvki iz pisem, statei, vystuplenii i traktatov [Masters of Soviet architecture on architecture: Selected excerpts fromletters, articles, speeches and treatises], in 2 vol., M. G. Barkhin (ed.). Moscow, Iskusstvo Publ., 1975.

25. Khronika [Chronicle]. In: Arkhitektura Leningrada [Architecture of Leningrad], 1939, no. 2, pp. 76-77.

26. Ginzburg A.M., Kirikov B.M. (authors-comp.). Arkhitektory-stroiteli Sankt-Peterburga serediny XIX - nachala $X X$ veka : Spravochnik [Architects-builders of St. Petersburg in the mid-XIX - early XX century: Reference]. Saint Petersburg, Piligrim Publ., 1996, pp. 223-224.

27. Zodchie Sankt-Peterburga. XX vek [Architects of St. Petersburg. XX century]. Saint Petersburg, Lenizdat, 2000, pp. 30-42.

28. Lidval' Fedor Ivanovich. In: Vikipediya [Wikipedia]. Access mode: https://ru.wikipedia.org (accessed 07.13.2020).

29. Ol' A.A. F.I. Lidval'. Saint Petersburg, 1914.

30. Lisovskii V.G. Mastera peterburgskogo moderna. Stranitsy tvorcheskoi biografii F.I. Lidvalya [Masters of St. Petersburg Art Nouveau. Pages of the creative biography of F.I. Lidvala]. In: Stroitel'stvo i arkhitektura Leningrada [Construction and architecture of Leningrad], 1980, no. 3. 
31. Pretro Ippolit Aleksandrovich. In: Vikipediya [Wikipedia]. Access mode: https://ru.wikipedia.org/wiki/Pretro,_Ippolit Aleksandrovich (accessed 07.16.2020).

32. Pretro Ippolit Aleksandrovich. In: DeloRus. Access mode: http://delorus.com/medialibrary/detail.php?ID=1926 (accessed 07.17.2020).

33. Isachenko V.G. Ippolit Pretro. In: VikiChtenie [WikiReading]. Access mode: https://design.wikireading. ru/13694 (accessed 06.25.2020).

34. Arkhitektor Rzhepishevskii [Architect Rzhepishevsky]. Access mode: https://old-akkerman.livejournal.com/10731. html (accessed 06.28.2020).

35. Rzhepishevskii Aleksandr Ivanovich. In: Vikipediya [Wikipedia]. - Access mode: https://ru.wikipedia.org/wiki/ Rzhepishevskii,_Aleksandr_Ivanovich (accessed 06.16.2020).

36. Polyakova Yu.Yu. Arkhitektory Khar'kova pol'skogo proiskhozhdeniya [Architects of Kharkov of Polish origin]. In: Pol's'ka diaspora u Kharkovi: istoriya ta suchasnist' [Polish Diaspora in Kharkiv: History and Modernity], Materials of Sciences. conf., Kharkiv, April 24. 2004. Kharkiv, Maidan Publ., 2004, pp. 111-124.

37. Serafimov Sergei Savvich. In: Vikipediya [Wikipedia]. Access mode: https://ru.wikipedia.org/wiki/Serafimov,_ Sergei_Savvich (accessed 07.19.2020).

38. Serafimov Sergei Savvich (1878-1939). In: Tramvai iskusstv [Art tram]. Access mode: https://tramvaiiskusstv.ru/ grafika/spisok-khudozhnikov/item/2092-serafimov-sergejsavvich-1878-1939.html (accessed 07.28.2020).

39. Ezhegodnik Obshchestva arkhitektorov-khudozhnikov [Yearbook of the Society of Artists Architects], 1927, Is. 12, pp. 109-122.

40. Ezhegodnik Obshchestva arkhitektorov-khudozhnikov [Yearbook of the Society of Artists Architects], 1930, Is. 13, pp. $96-97$.

41. Nekrolog [0bituary]. In: Arkhitektura SSSR [Architecture of the USSR], 1940, no. 1, p. 74.

42. Pamyatniki arkhitektury i istorii Sankt-Peterburga. Vasileostrovskii raion [Monuments of architecture and history of St. Petersburg. Vasileostrovsky district]. Saint Petersburg, Kolo Publ., 2006, pp. 445-446.

43. Leibfreid A.Yu., Polyakova Yu. Khar'kov. Ot kreposti do stolitsy : zametki o starom gorode [Kharkov. From the fortress to the capital: notes about the old city]. Khar'kov, Folio Publ., 2004, pp. 116-118.

44. Davidich T.F. Ploshchad' im. Dzerzhinskogo, GOSPROM i khar'kovskii konstruktivizm [Square them. Dzerzhinsky, GOSPROM and Kharkov constructivism]. In: Khar'kov. Ofitsial'nyi sait [Kharkov. Official site]. Access mode: https://www.kharkov. ua/culture/2b.html (accessed 07.29.2020).

45. Kravets Samuil Mironovich. In: Vikipediya [Wikipedia]. Access mode: https://ru.wikipedia.org/wiki/Kravets,_Samuil_ Mironovich (accessed 07.22.2020).

Давидич Татьяна Феликсовна (Харьков). Доктор архитектуры. Доцент кафедры основ архитектуры Харьковского национального университета строительства и архитектуры (61002, Украина, Харьков, ул. Сумская, 40. ХНУСА). Эл.почта: t.f.davidich@gmail.com.

Davidich Tatiana F. (Kharkov). Doctor of Architecture. Associate Professor of the Department of Fundamentals of Architecture at the Kharkiv National University of Civil Engineering and Architecture (40 Sumskaya str., Kharkov, Ukraine, 61002. KNUCEA). E-mail: t.f.davidich@gmail.com. 